京都府立医科大学, 第三内科学教室 (主任 : 增田正典教授).

IIIrd Dept. of Internal Med. (Head: Prof. M. MASUDA), Kyoto Prefectural Med. Univ., Kawara-machi, Kamikyo-ku, Kyoto.

\title{
鉄給与時におけるラット十二指腸吸収細胞の 微細構造の変化。
}

\section{Fine Structural Changes of the Rat Duodenal Absorptive Cells following Iron Administration.}

沖 啓 $\rightarrow$ Keiichi OKI.

(Received February 1, 1965.)

小腸粘膜の微細構造は, 1950 年初めて Granger と Baker によって報告されて以 来, 十二指腸および空腸粘膜, 特に吸収細胞の微細構造に関する数多くの詳細な 研究がある (Daltonら 1950, Dalton 1951, Weiss 1955, Zetterquist 1956, Palay ら 1959). また，小腸粘膜に打ける吸収機構を細胞学の立場から究明しょうとする 試み屯多数の研究者により行なわれて来た（Clark 1959, Fawcett 1958, Palay ら 1959, Schmidt 1961, Lacy ら 1962). 水之電解質の吸収時における小腸吸収上皮 細胞の微細構造の変化については Weiss (1955) 抒よび Ruska (1960) の研究があ る。なかであWeiss はナトリウムとカリウムの吸収時に打けるマウスの十二指腸 吸収細胞の糸粒体の内にいわゆる糸粒体顆粒が増加するととを認め, 初めて電解 質の吸収と系粒体の機能との関係を推定した。 また, Peachey $(1962,1964)$ は細 胞をカルシウム，ストロンチウム，バリウムなどの 2 価イオンオンで処理すると， 系粒体内の顆粒が増加するととを観察した。

一方, 近年鉄代謝の研究が進み, 種々の新知見があたらされているが, 鉄が腸 管粘膜を通って吸収される機構については未解決の問題が多い. 従来の生化学的 研究は腸管粘膜を 1 枚の膜とみなす考え方に基いており，鉄吸収の機構を詳細に 動的に観察するためにはごうしても細胞学の立場から観察してみる必要がある.

このような観点から著者はまず正常ラットにおける十二指腸吸収上皮細胞の微 細構造および鉄吸収時におけるその変化を観察し，他の陽イオンの塩化カルシウ ムと塩化ナトリウム吸収時の変化と比較検討し, 興味ある結果を得たのでことに 報告する。

\section{I. 材 料 と方 法.}

実験動物. 体重 $100 \mathrm{~g}$ ほどの幼若な雄性 Wistar 系ラットを一定期間オリエン タル固形飼料を与えてジュラルミン製の箱の内で飼育し, 実験の 24 時間前から狭 
い籠に入れて霬食を防ぎ，蒸留水のみを与えた．

給与薬剂の調製

1. 塩化第 1 鉄，塩酸を加えて強酸性の溶液として保存した塩化第 2 剑液に用 時苛性ソーダを加えて $\mathrm{pH} 1.6$ とし，アスコルビン酸を充分加えて還元し，水を 加えて $6 \mathrm{mg} / \mathrm{ml}$ および $0.6 \mathrm{mg} / \mathrm{ml}$ の塩化第 1 鉄液を調製じた.

2. 硫酸第 1 敛。貧血の治療に用いられている硫酸第 1 铁を蒸留水に溶かし, $6 \mathrm{mg} / \mathrm{ml}$ の液を調製した。

3. 塩化カルシウム．塩化第 1 鐏溶液 $6 \mathrm{mg} / \mathrm{ml}$ と等オスモル，すなわち 10.59 $\mathrm{mg} / \mathrm{ml}$ の塩化カルシウム溶液を調製した.

4. 塩化ナトリウム，塩化第 1 鉄溶液 $6 \mathrm{mg} / \mathrm{ml}$ の塩化ナトリウム溶液を調製し た。

以上の各薬剤はいずれあ使用直前に調製された。

薬剂給与方法。あらかじめ前述の如く準備された動物の胃内に，上記各薬剂 $0.5 \mathrm{ml}$ ずつをポリエチレン管を用いて直接に注入した.

試料の作製，薬剂給与後のラットを一定時間毎に断頭により屠殺した。屠殺後 速かに開腹し，幽門より約 $2 \mathrm{~cm}$ 遠位部の十二指腸を切りとり，その一部をただ ちに約 $4^{\circ} \mathrm{C}$ の四酸化オスミウム固定液で約 1 時間固定した。固定液は Caulfield （1957）あるいは Millonig（1962）の方法によって調整した。 その後ウラニールア セテート水溶液で 1 時間前染色を行ない, アルコールかアセトンにより脱水し， Luft の方法に従って Epon に包埋した。超薄切片は Porter-Blum 型ミクロトーム にガラスナイフを装着して作製した。切片はシートメッシュに張ったコロジオン 薄膜抢よびその上にカーボンを蒸着したものにのせた。切片の一部はウラニール アセテートのアルコール溶液; Millonig (1961) による酢酸鉛法あるいは Raynold （1963）による硝酸鉛法で染めた。観察には HU-11 A 型電子顕微鏡を用い，加速 電圧を $75 \mathrm{kv}$ とした。 写真は直接倍率 2,000-60,000 倍で撮影し，乙れを 2 -5 倍 に拡大印画して観察した。

また十二指腸の一部を中性ホルマリンで固定し，ヘマトキシリンーエオジン染 色およびベルリン青反応を行ない，光学顕微鏡による観察に供した。

\section{II. 実 験 結 果.}

\section{A. 正常ラットの十二指腸吸收上皮細胞の微細構造.}

正常ラットの十二指腸吸収上皮細胞の光学顕微鏡的と電子顕微鏡的の所見はす でに多くの研究者により報告されている。乙こに鉄および各種陽イオン吸収時の 変化を観察するに際して，著者自身まずラット 2 匹を正常対照群として，薬剤を 給与することなく屠殺し，微細構造を観察した。

十二指腸粘膜の表面には多くの上皮細胞が存在する（図 1). 吸収上皮細胞は柱 形で，単層に規則正しく配列している。核は中央よりやや基底の方に位置し，ほ 
ぼ楕门形を呈するが，所々ゆるやかな陥入を有する。切片によって $1-2$ 個の核 小体が明膫に見られるととがある。核膜は他の多くの細胞に打けると同様に内外

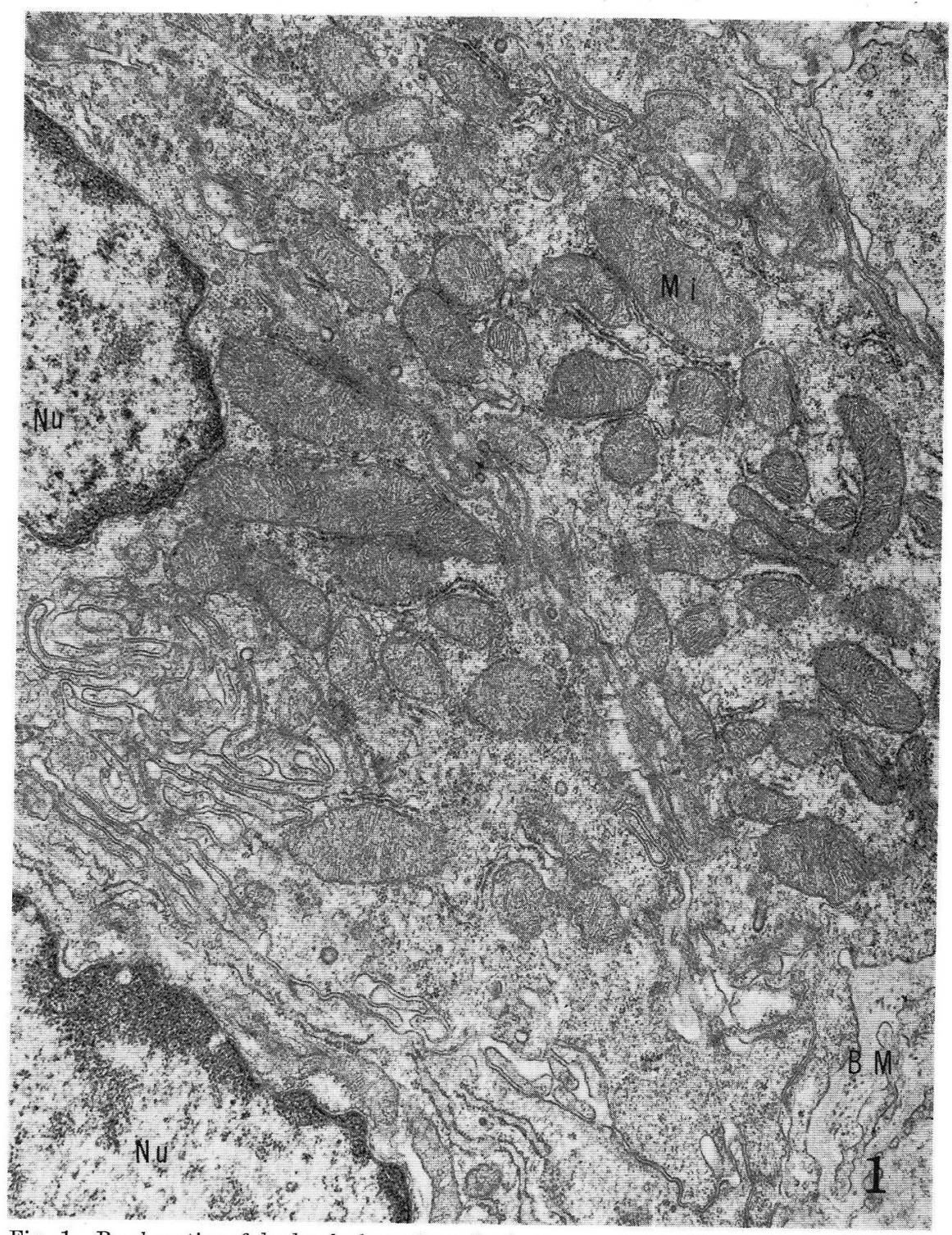

Fig. 1. Basal portion of duodenal absorptive cells from normal rat. Many mitochondria (Mi) are seen between the nucleus $(N u)$ and basement membrane $(B M) . \times 16,000$

の 2 枚に分別される。外核膜は内核膜よりも薄く, 一部は細胞質内に延長して粗 面小胞体に移行している. 
細胞膜は他の多くの細胞におけると同様 3 層棈造を呈し, 単位膜（unit membrane, Robertson 1959，1960）からなる。細胞の基底面を被う絒胞膜はほぼ直ぐに 走り，いわゆる基底陌入はほとんど見られず，その外に基底謨が接している。縕 胞側面を被う細胞膜は強い曲折を示し，隣接細胞との間にいわゆる細胞間䈈合 (intercellular digitation) を形成する。細胞自由面に近く細胞膜は肥厚し，いわゆ る閉鎖堤を形成する。乙れより少し基底の方において 1一数個の接着板がみられ， ことでも細胞膜は肥厚している。細胞の自由面を被う細胞膜は最も特異的であ り，規則正しく突出する無数の微絨毛の表面を忠実に被っている（図 2). 微絨毛

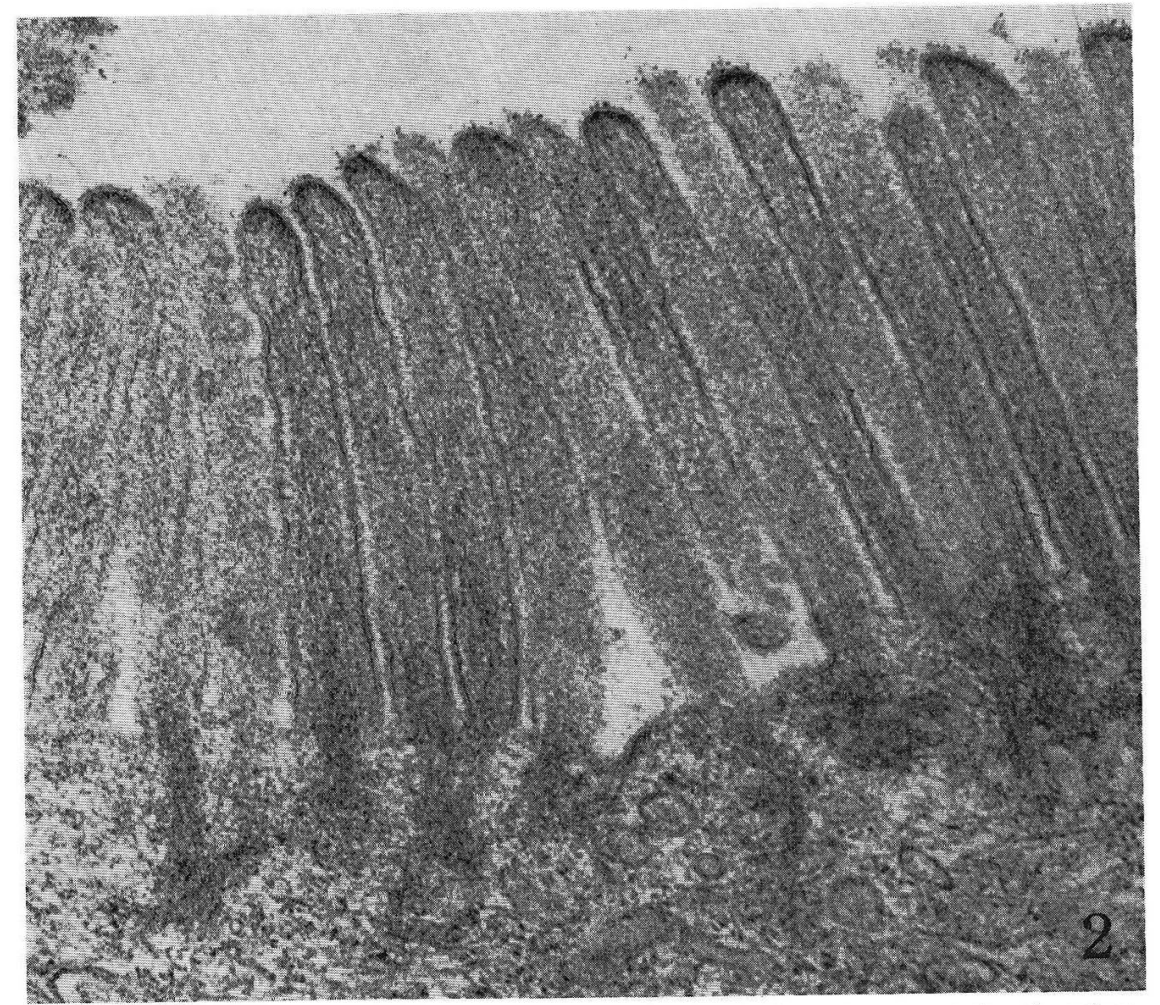

Fig. 2. Longitudinal section of microvilli from normal rat. Unit membrane covering the microvilli, and pinocytotic sacs between the microvilli are seen. $\times 75,000$

の起始部の細胞の自由面は種々の程度に細胞質中に陷入している。 細胞質の基質は中等度の電子密度を有し, リボソームむ中等量存在する。 微䋐毛は上记の加く, 細胞白由面の細胞質突起とその表而を被う細胞朕からな っている，光学顕微鏡で钼察される小支縁はこの微絨もにほかならない，微縅毛 の太さは斯底部，尖端部と屯ほぼ等しく，長さは絸胞により暴なり，0.5一2 に

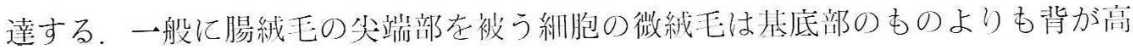




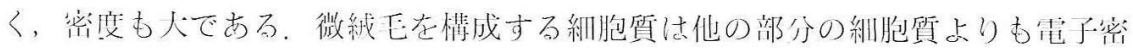

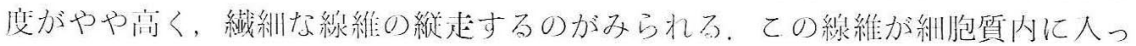

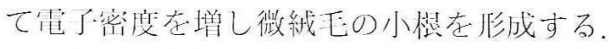

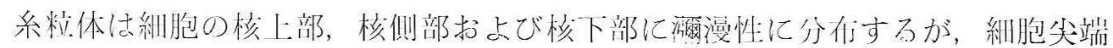

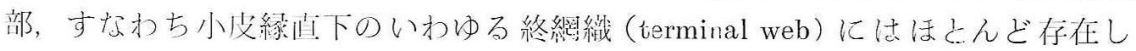

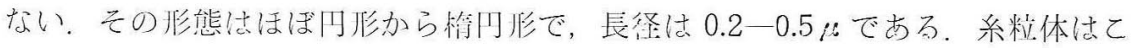

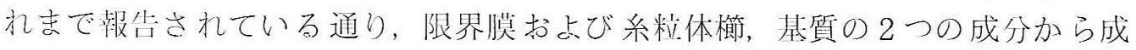

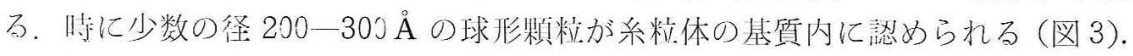

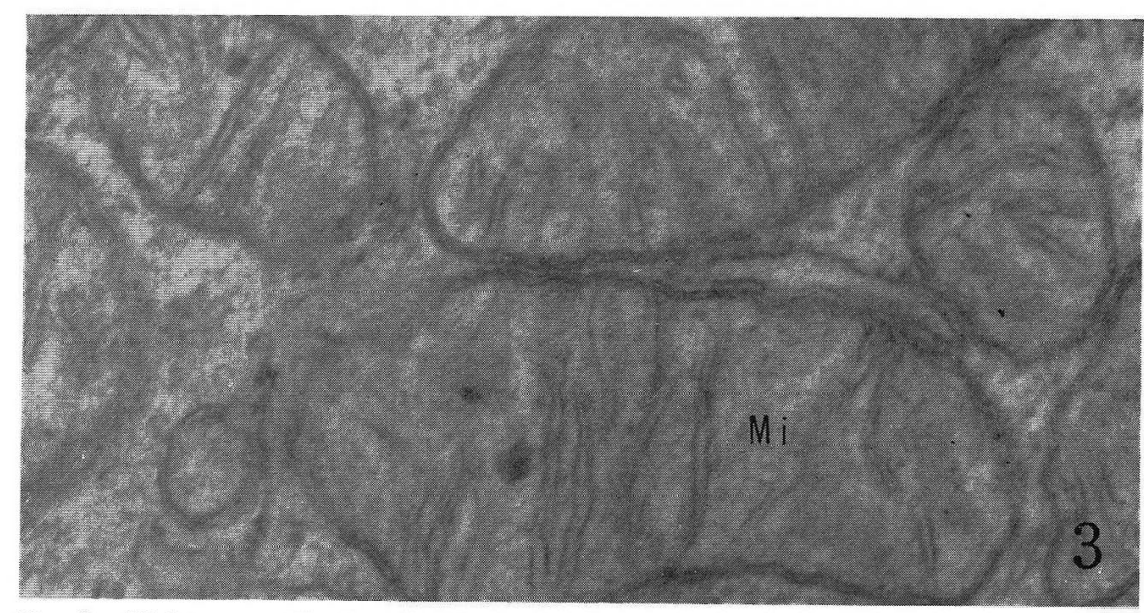

Fig. 3. Higher magnification of mitochondria from a duodenal absorptive cell of normal rat. $\times 75,000$

小胞体は他の多くの細胞と比較すると、等度に発達し，膜の上にリボソームの 付着した粗面小胞体であるものが多い，時には小胞体が系粒体の周囲をとりまい ている像がみられる。

Golgi 装置は Golgi 層板, Golgi 小胞, Golgi 空胞の 3 要素からなり，核上部によ くみられるが，概して発達が惩心。

デンス体 (dense body) は核上部に 1一数個みられ, 大きさは系粒体と同様か, または小さい，円形か卵円非で，多くは1枚の単位膜に包まれ，基質の電子密度 は高い，時には基質内に空胞や膜様構造がみられる。また，時には系粒体様の構 造物をもった大きなデンス体むみられる。

\section{B. 塩化第 1 鉄 $3 \mathrm{mg}$ 給与後のラットの十二指腸吸收上皮細胞の微細構造.}

塩化第 1 鉄 $3 \mathrm{mg}$ の給与後 30 分および 1 時間に各 2 匹，2時間および 3 洔間に 各 4 匹 (計 12 匹) のラットを殺して観察した.

光学顕微鏡的には, 腸䋐毛を被う柱版上皮細胞は全体に薄く, ベルリン青反応 
が陽性であるが，とくに絨毛の尖端部を被う收収上皮は比較的強い反灾を呈す

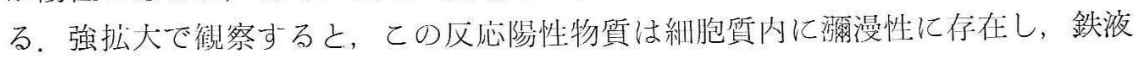
給与後 2 時間のラットにおいて最も強い反応を呈する.

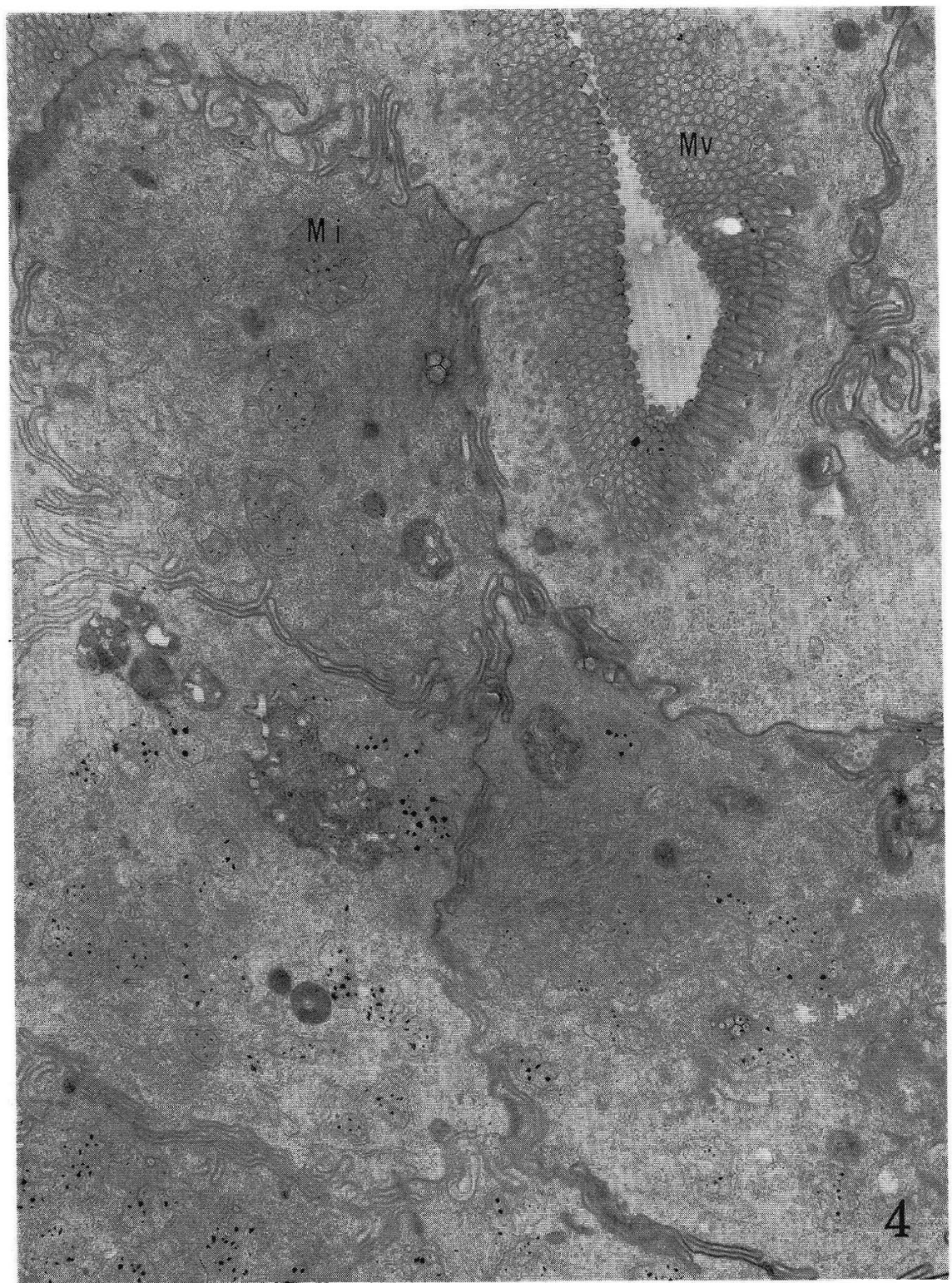

Fig. 4. Apical portion of several duodenal absorptive cells from the rat, 2 hours after gastric infusion of $3 \mathrm{mg}$ of ferrous chloride. Many electron dense granules are seen in the mitochondria (Mi). $M v$ microvilli. $\times 12,000$ 
次に電子顕微鏡による観察に入るが，まず，塩化第 1 鉄液給与後の各時閒に抒 ける吸収細胞の微細構造の変化を総括して記述する。

吸収細胞の核，核小体，核膜，細胞質の基質，リボソーム，Golgi 装置および小 胞体には著明な変化はみられず，正常対照群の所見と大体同様である（図 4).

糸粒体の数と分布には変化が珰められないが，限界膜の走行と系粒体楖の配列 がやや乱れ，基質の電子密度も不均一となっている，最も注目すべき変化は糸粒 体内に大きな，電子密度の高い顆䊀が出現したととである（図 4，5，6，7）．この 系粒体内顆粒の形態学的特微を詳細に記載すると,

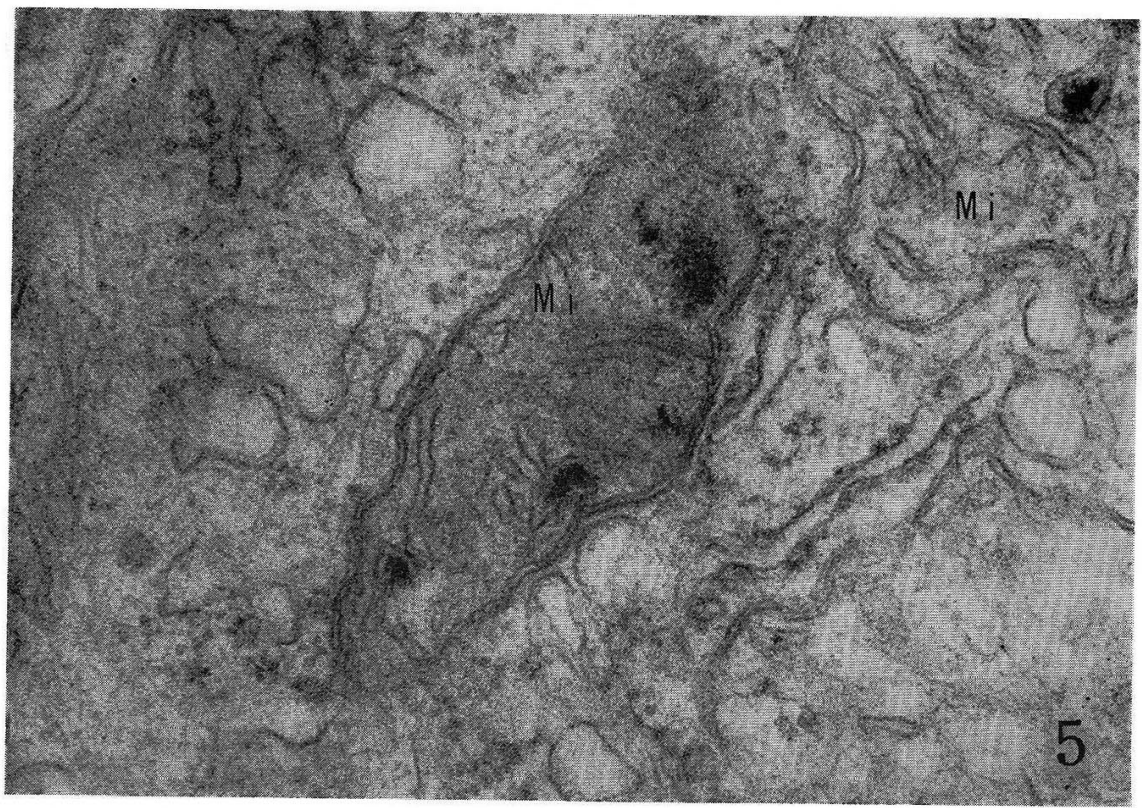

Fig. 5. Three mitochondria from the same rat as in Fig. 4, having several electron dense granules in the cristae and an aggregation of fine particles in the matrix. $\% 75,000$

顆粒はすべて糸粘体櫛および限界膜の川に存在する（図 5, 6, 7). 糸粒体櫛扢 よび限界膜は 2 枚の膜および中間層の 3 層構造を示すが, 顆粒はその比較的明る い中間層に存在する。また，顆粒をもった糸粒体櫛の横断面では，顆粒の周围を 明るい軍がとりまき，さらにその外侧を 1 枚の膜がとりまく。また，後述の如く， この顆䊀は大きく，時には $500 \AA$ にも達するために，顆粒をあった糸粒体櫛また は限界膜は膜全体の幅が増大し，時には $600 \AA$ 以上に達することがある。顆䊉の

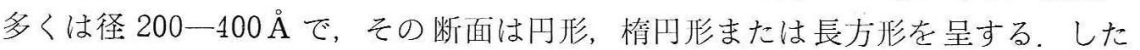
がってこの顆粒の立体像は球形か, 卵形か, 短い円柱形に現われる。またこの顆 粒の表面の所見と特に薄い切片の観察から，顆粒がさらに微細な粒子から構成さ れているととがわかる(図6). 


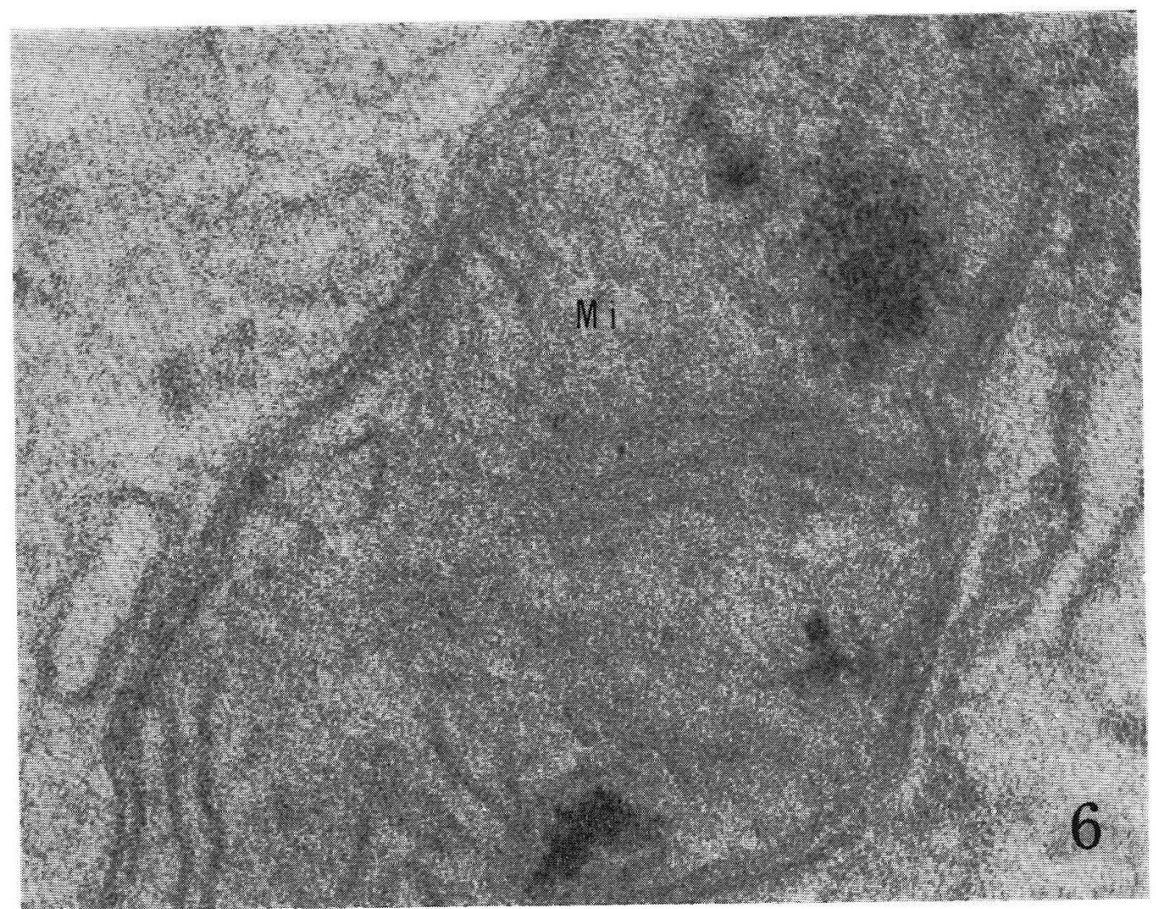

Fig. 6. Higher magnification of the Fig. 5. An electren dense granule in the cristae mitochondriales (at the bottom of the figure) is composed of numerous fine particles, as well as the granules or aggregation in the matrix (at upper right). $\ 200,000$

系䊀体の 1 つ0断面における顆粒の数は㮔々であり，1-20 数個を数えるが， 5 一10個をもつ系粒体が最も多い.

以上のような形態学的特微によって, 問題の顆粒は正常ラットの收収絸胞の糸 粒体で観察される系粒体基質内の頪粒とは容界に識別しうる。この顆粒は概し て，絨毛尖端部を被う吸収細胞に多く，陰简に向うにつれて少なくなる倾向にあ

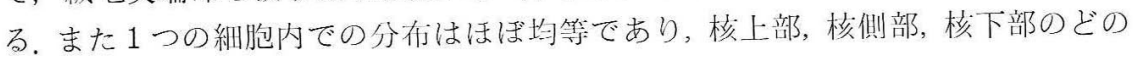
部分の系粒体も扝よそ同数の顆粒を有している。

以上記述した糸粒体膜内の顆粒のほかに，図 5，6，7 にみられるように，系粒。 休基質の中にも微細な䊀子がまばらな集合を作る像屯みられる。乙の部をさらに 強拡大で観察したのが四 6 である。粒子の大ささは系粒体膜内の顆粒を構成する 微細な粒子の大きさとほば一致する。

系粘体膜内に顆粒をむち，または基質内に微細粒子をもつ系粒体においては， 正常ラットの糸粒体基質内にみられた顆䊀は全く認められない.

次に塩化第 1 鉄給与後の各時間における收収上皮細胞の微細棈造の変化を比較 観察する.

最も著明な変化は 2 時間後にみられ，十二指腸吸収上皮細胞には膜内に顆粒を 


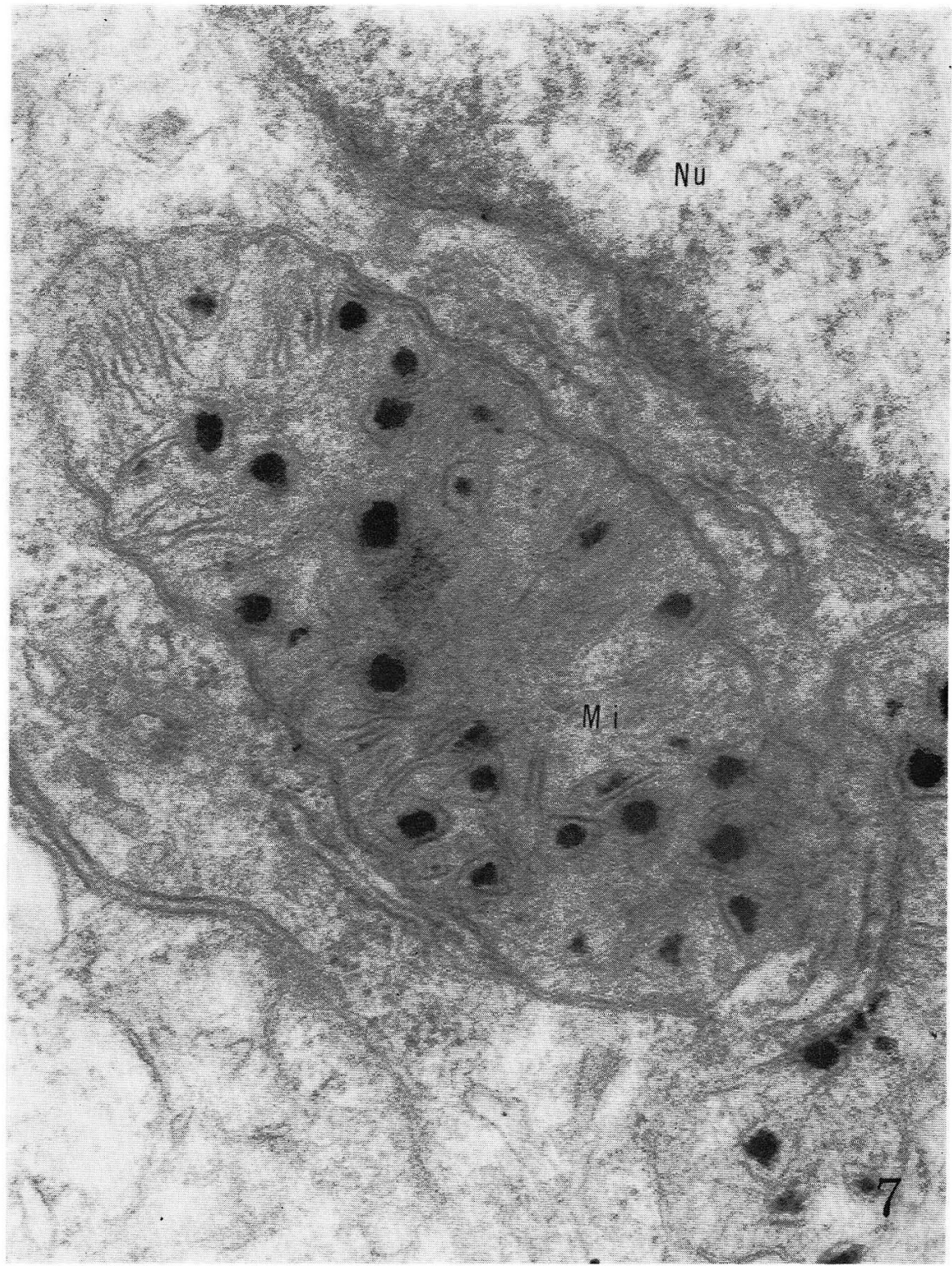

Fig. 7. Two mitochondria near the nucleus from the same rat as in Figs. 4, 5 and 6 . The central one has 30 granules in its cristae and an aggregation of fine particles in the matrix. The other mitocaondrion at lower right has granules in the limiting membrane. $\times \mathbf{7 5 , 0 0 0}$

あつ系粒体が多く認められ，その数は他の恃間におけるよりも多く，十二指腸絨 毛の尖端部の吸収細胞のほとんどすべての糸粒体に多数の顆粘がみられる，洔に は，糸粒体の1つの断面に 30 個に近い顆粒を認めることもある(図 7). 


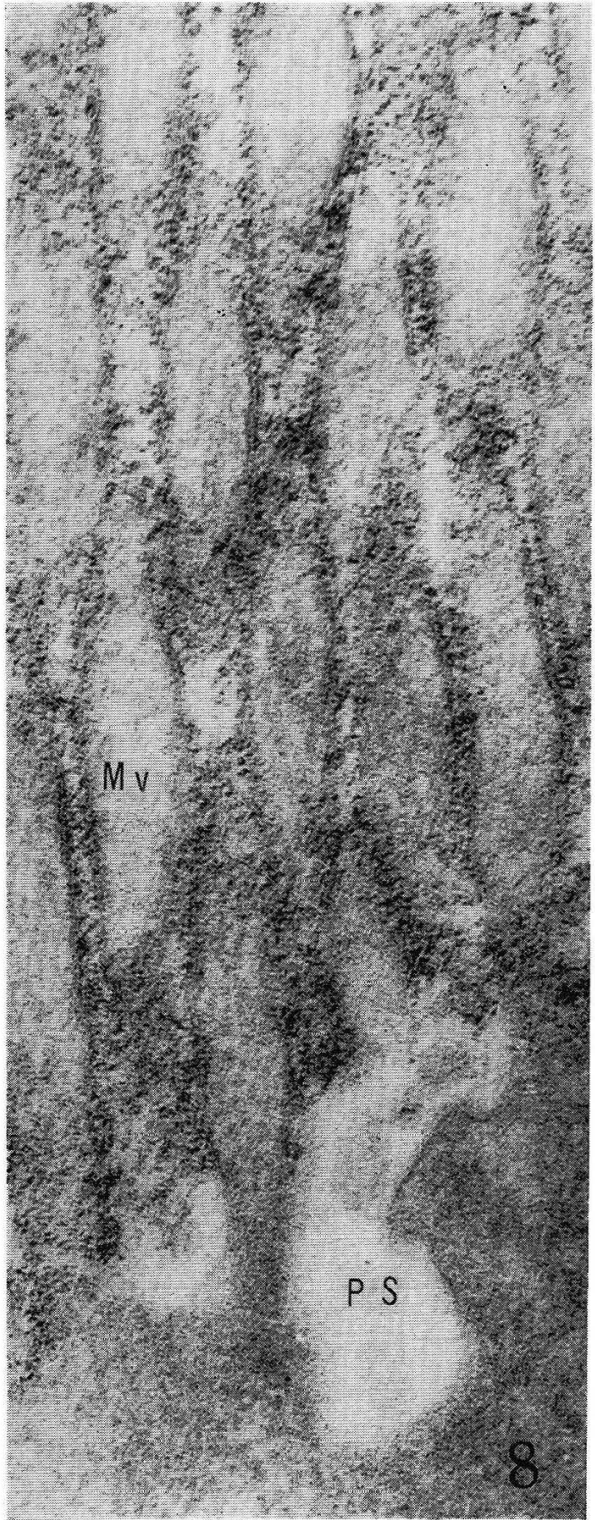

Fig. 8. Longitudinal section of microvilli of a duodenal absorptive cell, 30 minutes after gastric infusion of $3 \mathrm{mg}$ of ferrous chloride. Note many small particles attaching to the outer and inner side of the unit membrane which covers the microvillus. But particles ere absent on the membrane lining pinocytotic sac. $\times 129,000$

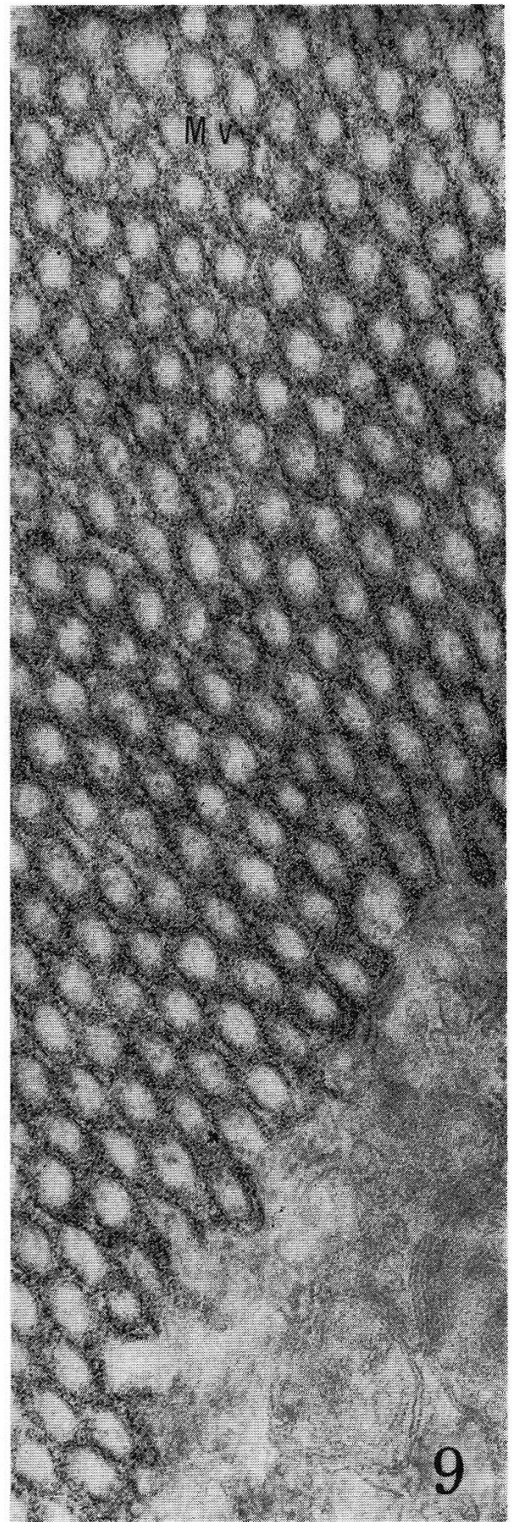

Fig. 9. Oblique section of the same specimen as in Fig. $8 . \times 50,000$ 
30 分， 1 時間，3 時間後に屠殺したラットのいずれにも，膜内顆粒をむつ系粒 体の数と $1 つ の$ 系粒休断面内の顆粒の数がともに 2 时間後よりも少ない.

30 分後に屠殺したラットの 1 匹での目立った異常の像は, 図 8 と 9 に示され たように，微䄉毛に微練な粒子の付着した練胞が現われたてとである。との像を さらに詳細に観察すると，微細な粒子は微絨毛の表面を被う単位膜の外膜の外面 および内膜の内面の両方に付着しているが，微紱毛の内部には粒子はみられない し，また，微䋐毛の起始部において細胞質の方に陌入している細胞膜 (pinocytotic sac）にはこの種の粒子は全くみられない.

3 時間後に殺したラットの 1 匹には細胞質の中に变形した糸粒体をもつ 1 種の リソソーム (lysosome, Novikoff ら 1956, Novikoff 1959, Essner ら 1960) か チト リソソーム (cytolysome Novikoff 1960) に該当すると考えられる構造物が多くみ られた。 このようなチトリソーム内の系粒体む膜内に顆粒を有する(図11と12).

また，この洔間では，基底膜の直下に存在する非上皮性の細胞にも，吸収上皮 細胞の系粒体膜内の顆粒と同様の顆粒をむつ細胞質内封入体がみられた（図 10）.

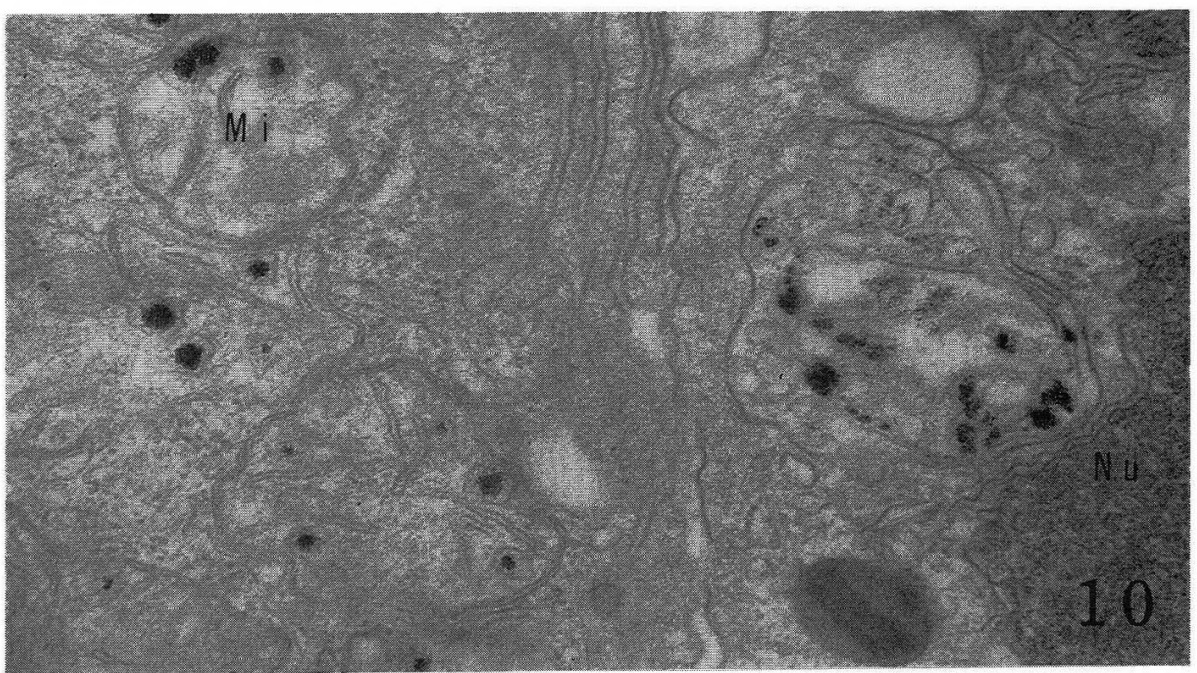

Fig. 10. A part of two different types of cells from the rat given $3 \mathrm{mg}$ of ferrous chloride 3 hours previously. At the left is an absorptive cell, and at the right is a wandering cell. Elèctron dense granules similar to those in the cristae mitochondriales of the absorptive cell are also seen in the cytoplasmic inclusion body of the wandering cell. $\times 50,000$

上記のように糸粒体の膜内に現われる顆粒の数は鉄液給与ののち2時間でピー クに達し，3時間後にはすでに減少を示した，塩化第 1 鉄 $3 \mathrm{mg}$ 投与により，多く のラットは衰弱し，4洔閒以降の観察が不可能になった。ラットが死亡，または著 しく衰弱したのは大量の鉄給与によるいわゆる鉄ショックによるものと考えられ た.よって著者は次に塩化第 1 鉄の給与量を減じて $0.3 \mathrm{mg}$ とし, 4 時間以後吸収 上皮細胞の微細構造の变化の微察を続けることを仼みた。 

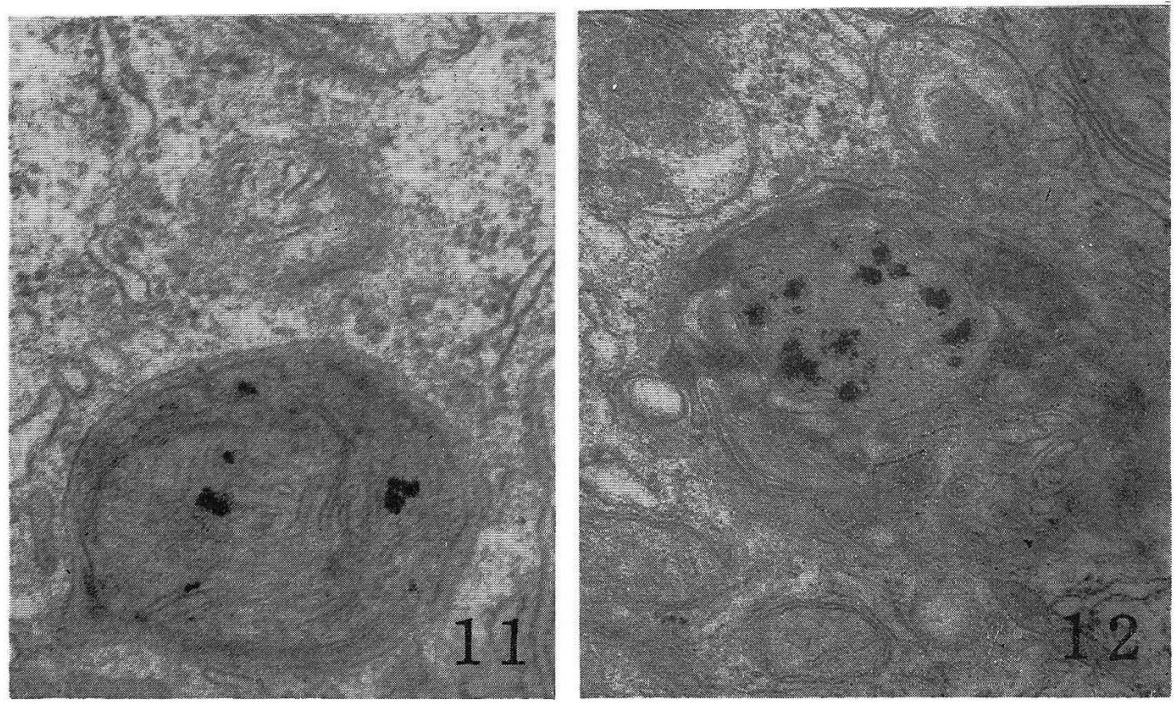

Figs. 11 and 12. 'The eytoplasmic inclusion bodies or denatured mitochondria having many dense granules in the membranous structures which are probably cristae mitochondriales. $\% 75,000$

\section{C. 塩化第 1 鉄 $0.3 \mathrm{mg}$ 給与後のラットの十二指腸吸收上皮細胞の微細構造.}

塩化第 1 猃 $0.3 \mathrm{mg}$ 䁌内に注入したのち $2,3,4,5,6,8$ 洔問にラットををれ ぞれ 2 匤ずつ屠殺し，十二指晹收収上皮細胞の微絒槛造の少化を長く微察した。

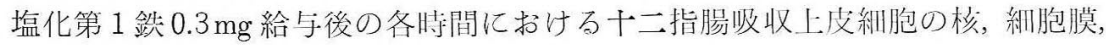
小皮縁, Golgi 装置は正常刘照群と何ら変りはなかった。

$0.3 \mathrm{mg}$ 給与後 2 時間および 3 時間のラットでは，十二指腸吸収上皮細胞の糸粒 体には $3 \mathrm{mg}$ 給与群におけると類似した変化がみられた。すなわち, 糸粒体の限 界膜の走行扔よび糸粘体櫛の配列がやや乱れ, 系粒休基質の電子密度もやや不均 一となる。さらに，系粒体の限界膜之系粒体櫛の中に $3 \mathrm{mg}$ 給与群に見られた顆 粒之類似した顆粒が観察された（図 13，14）. その形態学的特微は次の如くであ る。顆粒は系粒体の限界膜および櫛在構成する中問層の内に存在する。その断面

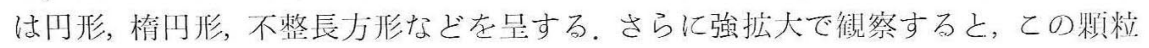

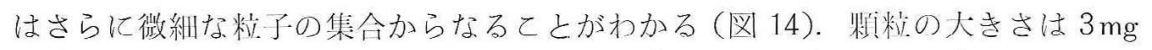

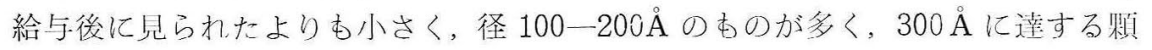
粒はまれである。系粒体の1つの断面の内に存する頪粒の数は程々であるが，5一 10 個を数える場合が多く, 稀にはそれが 20 数個に達する.

以上の如く, 塩化第 1 鉄 $0.3 \mathrm{mg}$ 給与後の 2-3 時間に糸粒体にみられる変化は $3 \mathrm{mg}$ 給与後にみられた変化と基本的に変るところがなく, 違うのはおあにただ 顆粒の大きさが小さいだけである。また，系粒体膜内の頪粒のほかに，系粒体基 質の中に微細な粒子がまばらな集合をつくって分布する像も見られた。 


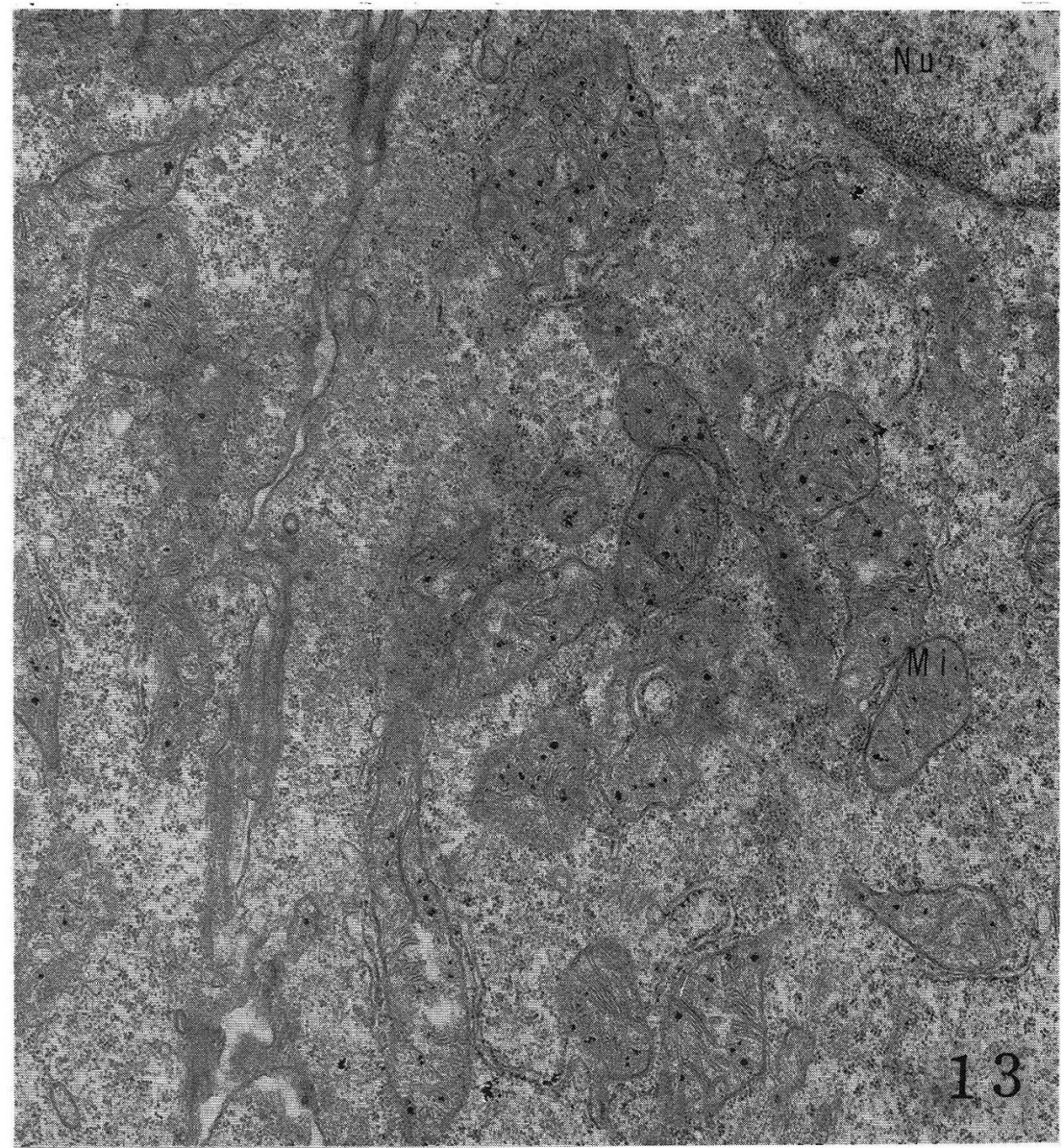

Fig. 13. Subnuclear portion of two absorptive cells, 2 hours after gastric infusion of $0.3 \mathrm{mg}$ of ferrous chloride. Note many dense granules in almost all mitochondrial profiles. $\times 16,000$

2 時間と 3 時間後に殺したそれぞれ 2 匹のラットの上皮細胞には， $3 \mathrm{mg}$ 給与 3 洔䦥後のラットの 1 匹にみられたようなチトリソーム (cytolysome) が観察され なかった。また 3 时間後のラットの十二指腸粘膜の非上皮性細胞には特記すべき 変化はみられなかった。

4 時閒と 5 洔間後のラットでは, 系粒体の变化は 2 時間之 3 洔間後のものにく

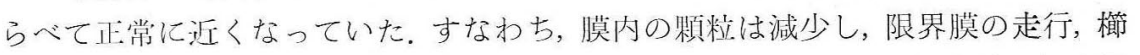
の䦿列の乱杞も少なくなっていた。系粘体以外の細胞内小器管, 細胞質, 細胞膜 抢よび核には正常と何ら変化がなかった。

6 将間後の 2 匹のラットのうちの 1 匹には四 15，16，17にあるように，吸収 細胞の細胞質川に脎約 50-60Aの䊀子の集合している像が思当たる。この䊑子 


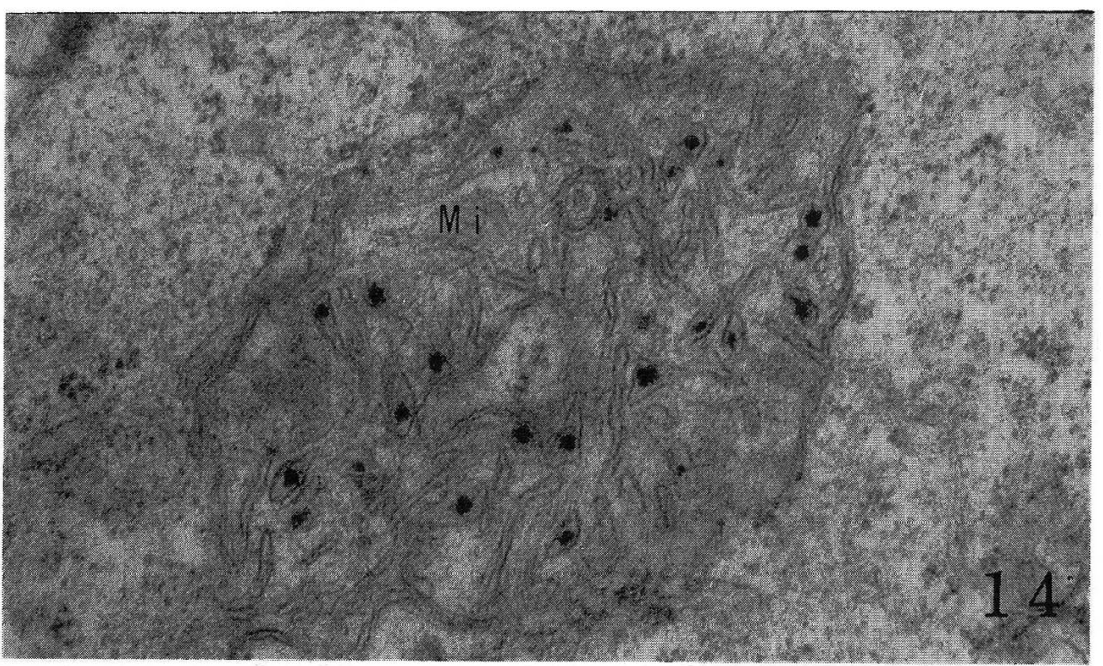

Fig. 14. Higher magnification of the Fig. 13. This micrograph shows that dense granules locate in the cristae mitochondriales, and that the size of the granules is smaller than those in the rat given $3 \mathrm{mg}$ of ferrous chloride. $\times 50,000$

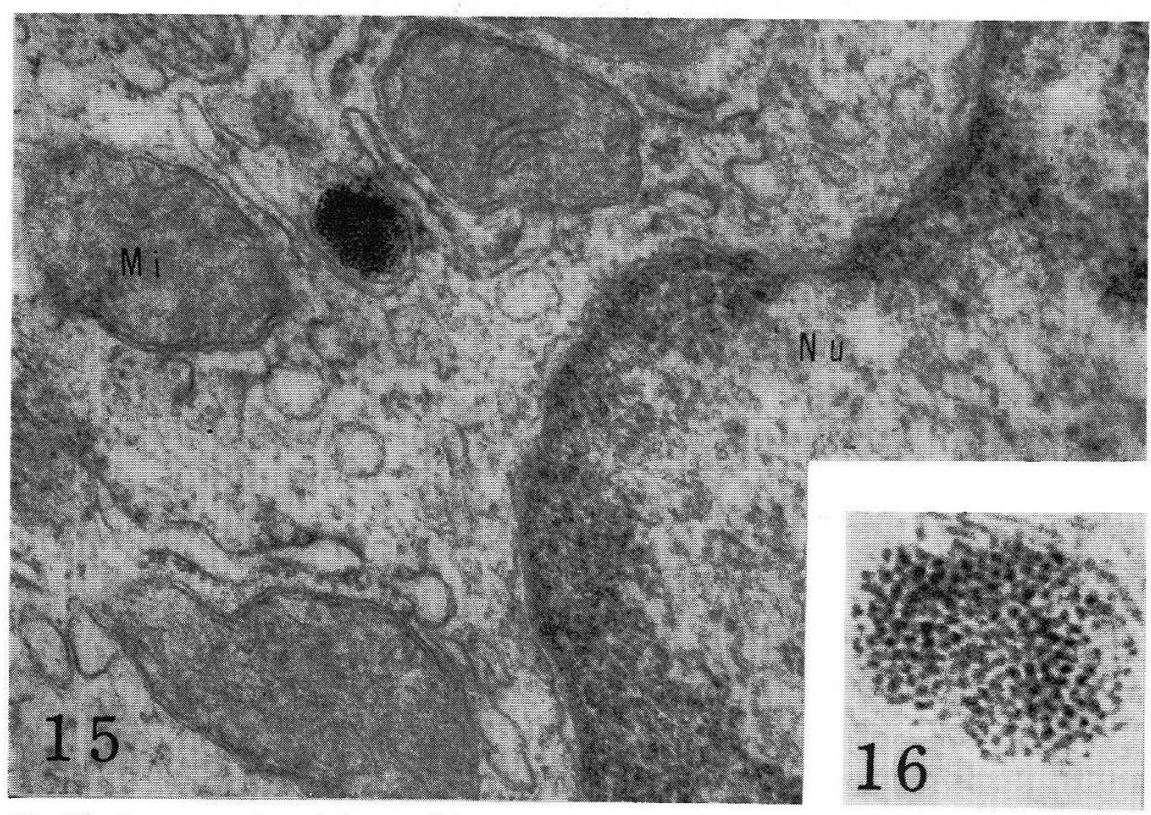

Fig. 15. An aggregation of ferritin-like particles in the cytoplasm of an absorptive cell, 6 hours after gastric infusion of $0.3 \mathrm{mg}$ of ferrous chloride. Mitochondria have normal structures. $\times 75,000$ Fig. 16. Showing a high magnification of the aggregation of the ferritin-like particles in Fig. 15. 


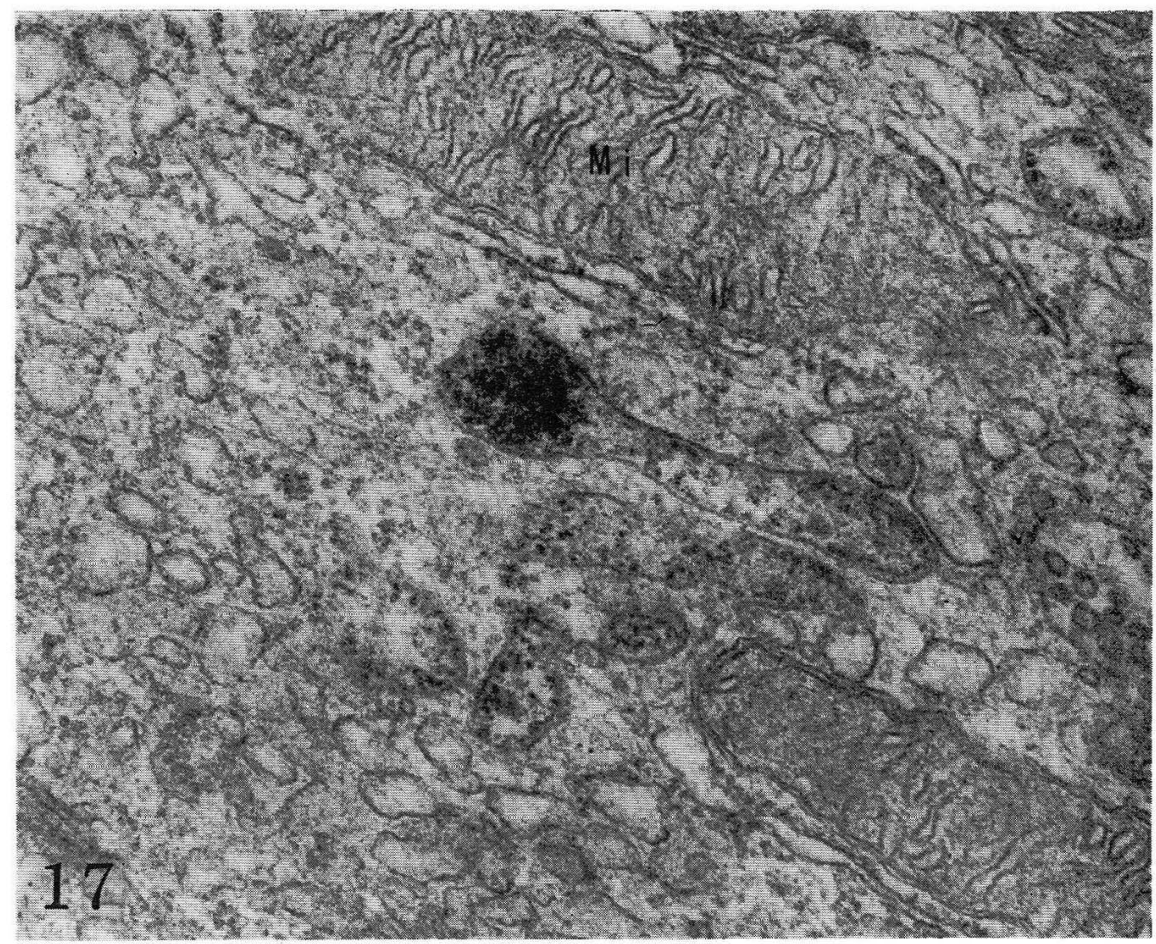

Fig. 17. An aggregation of ferritin-like particles in the cytoplasmic inclusion body of an absorptive cell from the same rat as in Fig. 15 . $\times 75,000$

は大きさ，形態扰よび電子密度が Farrant (1954), Bessis ら (1960) およよ゙ Richter (1957) のいうフェリチン粒子に類似する（図 16）。 また，てのフェリチン様粒子 の集合体は図 15 の如く，粗面小胞体に一部とりまかれているすのや，他に類似を 求得ない 1 枚の膜をあった基質の中に存在するあのあある(図 17). その他, 多くの系粒体および他の細胞内小器管には特記ずへき変化が見出せなかった．

8 時間後に屠殺した 2 匹の十二指腸吸収上皮細胞の微細構造は殆んど正常刘照 群のもの之同様であり，系粒体膜内の顆粒もみられなかった。

以上を要約すると，塩化第 1 鉄を $0.3 \mathrm{mg}$ 給与したのち 2 - 3 洔間の十二指腸吸 収上皮細胞の糸粒体の変化は前記の $3 \mathrm{mg}$ の場合と似ており，目立つのはただ膜 内の顆粒の大きさが小さいだけであった。 また，その数は 2 峙間に極大に達し， 3 時間後にはすでに減少し始め，6-8 時間後にはほとんど認められなくなった。 その他にはどのような形態学的变化あ認められなかった，また，すべてのラット において，前記 $3 \mathrm{mg}$ 給与後に現われたような特䅀な系粒体，すなわちチトリソ 一ムの内やなお非上皮性細胞の内に顆粒が認められなかったのである，特記すへ きととは，6洔間後に細胞質中にフェリチン様粒子の集合像がみられたことで， これは鉄吸収動態の 1 つの相を示すものとして重要な所見である。 


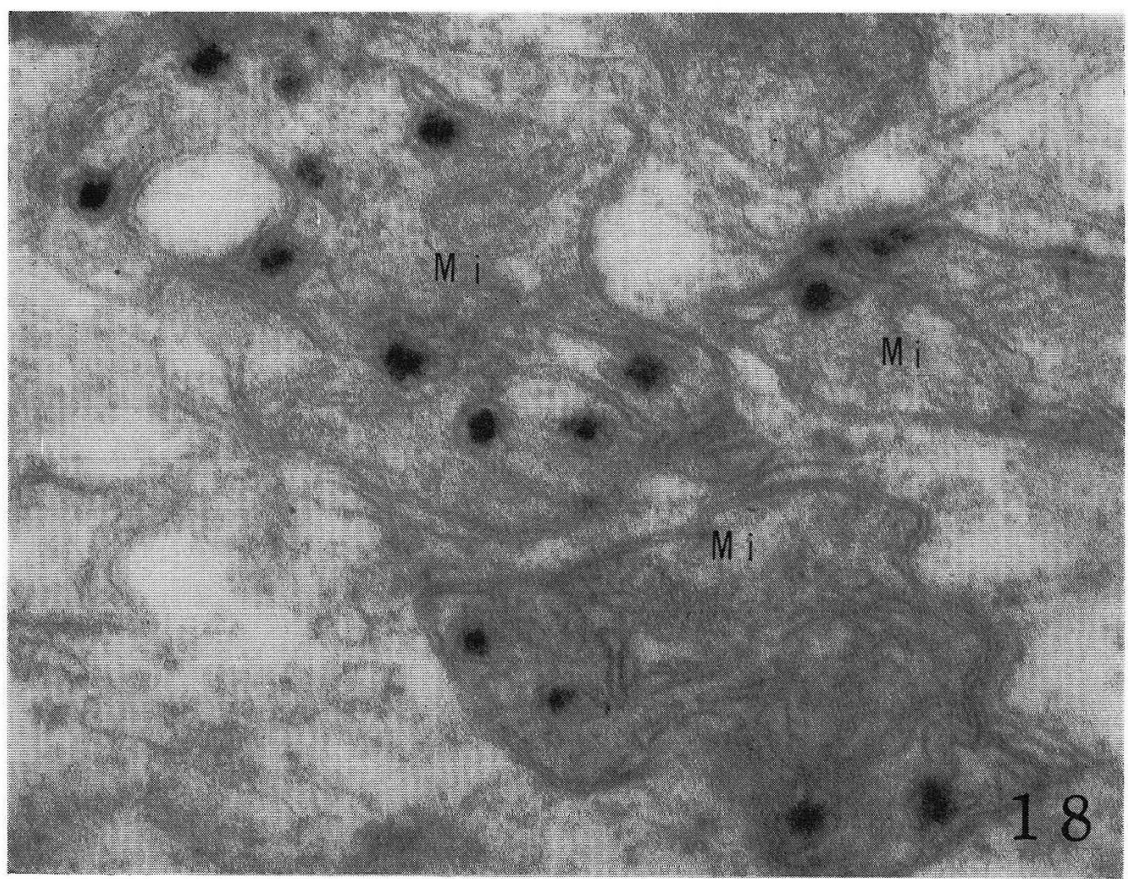

Fig. 18. Three mitochondria in an absorptive cell, 2 hours after gastric infusion of $3 \mathrm{mg}$ of ferrous sulfate. Note many granules in the cristae and limiting membranes of the mitochondria. $\times 75,000$

\section{D. 硫酸第 1 鉄 $3 \mathrm{mg}$ 給与後のラット十二指腸吸收上皮細胞の微細構造.}

硫酸第 1 鉄 $3 \mathrm{mg}$ 給与後 2 時間で屠殺した 2 匹のラットの十二指晹收収上皮細 胞の細胞内小器管，細胞質，細胞膜，核は正常対照群のそれとほぼ同様であり，系 粒体は塩化第 1 敛 $3 \mathrm{mg}$ 給与後 1 -3 時間で屠殺したラットのあのと類似した变 化を示した（図 18）。すなわち系粒体限界膜の走行, 櫛の限列がやや乱れ, 基質 の電子密度が少し不均一となり，系粒体櫛之限界膜を棈成する中間層に電子密度 の非常に高い顆粒が見られる。乙の顆粒の存在部位はもちろん，非態求よび数も， 塩化第 1 鉄給与の場合とほぼ同様である。ただ颗粒の大きさがやや小さく, $500 \AA$ をこえるものはなかった。

\section{E. 塩化カルシウムおよび塩化ナトリウム給与後のラットの 十二指腸吸收上皮細胞の微細構造.}

次に，比較対照のために，塩化カルシウムおよび塩化ナトリウムの吸収時の十 二指腸吸収上艾細胞の变化が倠察された。

塩化カルシウムが給与されたのちの1，2，3，4，5時間にラットがそれぞれ 2 匹 ずつ検べられ，また塩化ナトリウム給」後には 2 洔間で 2 匹が検べられた。 
塩化カルシウム給与 $1,2,3$ 洔間後の吸収上皮細胞の細胞内小器管, 細胞質, 細 胞膜，核には正常対照群のものと違いがなく，系粒体は図 19 に示されたように， 塩化第 1 鉄 $3 \mathrm{mg}$ 給与後 1,2 扣よび 3 洔間後に扣りる糸粒体と類似した変化を 示す．すなわち系粒体の限界膜の走行，櫛の唒列がともにやや乱れ，基質の電子

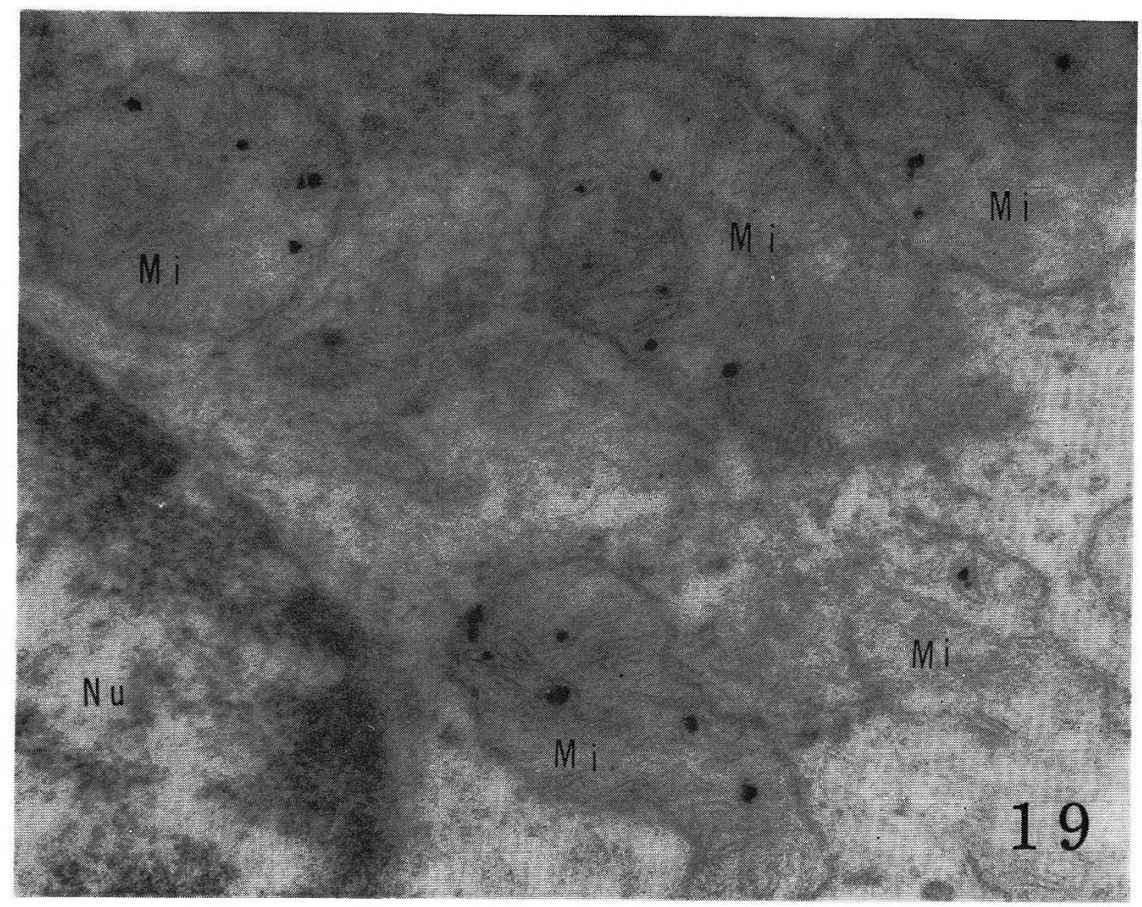

Fig. 19. A part of the cytoplasm near the nucleus of an absorptive cell, 2 hours after gastric infusion of calcium chloride. Many dense granules are seen in the mitochondrial membranes. These granules are smaller in size and of less density than those of the mitochondria from the rat given ferrous chloride and ferrous sulfate. $\times 75,000$

密度が不均一となり，さらに櫛と限界膜のうちに電子密度の高い顆粒が数多く観 察される。との顆粒の存在部位と形態も塩化第 1 鉄のときとほぼ同様であるが, 数は比較的少なく，系粒体の 1 つの断面に 20 個以上が米る像は少なかった。 ま たその大きさむ比較的小さく，径 $500 \AA$ を超えるものは来な加た．4時間後に は系粒体膜内の顆粒の数は減じ，その他の系粒体の変化も軽くなった。さらに，5 時間後にはほとんどすべての糸粒体が正常対照群のものと変りがなくなった．

次に塩化ナトリウム給与後 2 時間の 2 匹のラットでは吸収上芚細胞の小器管, 紐胞質，細胞膜，核が正常対照群の屯の之殆んど異ならず，系粒体も，その限界膜 の走行と櫛の配列はほぼ正常で，基質の電子密度も均一であった。なお，櫛と限 界膜中には顆粒は出現しなかった。ただ，正常刘照群にもみられたと同様の顆 粒が系精体の基質の山に埋むれて存在し, その数と大きさが增加し, かつ基質 

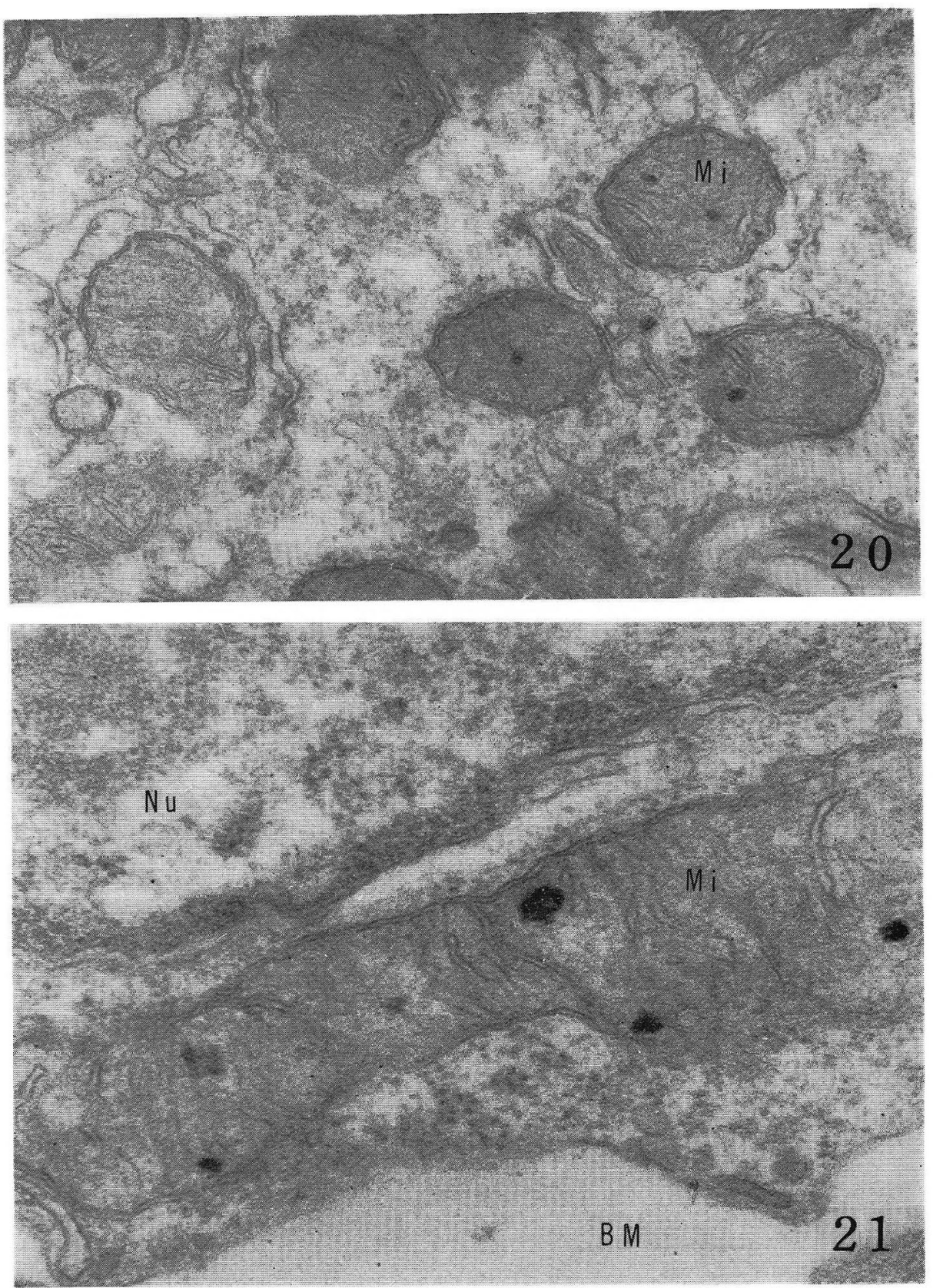

Figs. 20 and 21. Basal portion of an absorptive cell from the rat given sodium chloride 2 hours previously. The dense granules in the matrix of the milochondria are much in number than those in normal rat. $\times 50,000$ and 75,000 
の電子密度がやや不均一らしくなっていた（図 20). 時には糸粒体の 1 つの断面 に 4-5 個の顆粒が来る像もあり，また径が $300 \AA$ を超える顆粒もみられた（図 21).

以上を要約すると, 塩化カルシウム給与後の $1,2,3$ 時間の糸粒体にも限界膜 の走行および櫛の配列の乱れ，基質つ電子密度の不均一化，および膜内の顆粒の 出現がみられた，系粒体におけるこれら一連の変化は塩化第 1 鉄 $3 \mathrm{mg}$ 扝よび $0.3 \mathrm{mg}$ 給与の $1,2,3$ 時間後抒よよび硫酸第 1 鉄 $3 \mathrm{mg}$ 給与の 2 時間後の糸粒体 の変化によく類似し，形態学的には全く区別出来ない，換言すれば，系粒体の変 化，乙とに系粒体膜内の顆粒の出現は鉄吸収時の特異的な変化とのみ考えること ができない.

\section{III. 考 察.}

小腸粘膜叹収細胞の微細構造の研究は古くから Granger ら (1950), Dalton ら (1950，1951）らによって行なわれて来たが，当時は試料作製技術が十分でなく， 現時においては参考に供しがたい. その後，超薄切片作製法の進歩とあいまって Weiss (1955), Zetterqvist (1956) 拈よび Palay ら（1959）が詳細な研究を行なっ た。とくに Weiss はマウスの十二指腸粘膜を, Palay らはラットの空腸粘膜を観 察し，吸収上皮細胞が同じ腸絨毛上の位置によってもその微細構造に差異の来る ことを述べている，著者が今回観察した正常ラットの十二指腸吸収上皮細胞の微 細構造あ基本的には Palay らの報告とあまり差がなかった。

小腸吸収細胞の微絨毛については例えば Palay ら（1959）と本陣ら (1961)の 研究がある。著者む微絨毛内を緹走する線維や微絨毛起始部の細胞の自由面の陥 入を認めた。また，微絨毛直下の細胞質内のいわゆる終網織 (terminal wed) には, ピノチトーシス小胞と呼ばれる膜構造が見られた. Palay (1959) はこの細胞 膜の楩入掞よびピノチトーシス小胞は脂肪の吸収に密接な関係をもつ場合のある ことを実験的に証明した。

微絨毛の長さ，幅および密度はてれまでの報告に多少の差異があるが，乙れは 動物の種類, 腸管の部位, 組織固定法の違いによる差異とあ考えられるが, 著者 は同一のラットの同じ腸管の部位でも細胞により大きな变異のあるととを確認し た. Palay らのいう如く, 絨毛の尖端部を被う細胞は陰窩の細胞よりも長い微䋐毛 をもって拈り, 長い微絨毛は幅も広く, 密生している. 従って, 著者はその実験に これらの微䄉毛の計測值の意義を認めるてとができなかった。

微緁毛が吸収機能に大きな役割を演じているととは疑う余地のないととであ り, 微䄉毛の形態が細胞により異なるととは, 吸収機能も細胞により異なること を意味するものである。すなわち，䋐毛尖端部を被う細胞は基底部の細胞よりも 吸収機能が大であると考えられる。

小腸吸収細胞の系粒体については最初に Palade（1952）の咩細な報告があり， 
基本的には著者の観察結果もとれに一致した。

系粒体内の顆粒は Palade (1952) が 小腸粘膜上皮細胞と腎尿細管上皮細胞につ いて，また Sjöstrand とRhodin (1953) が腎尿細管上皮細胞について最初に記載 している。そののち，他の細胞においても同様の顆粒の存在が多くの研究者によ り報告されている。乙の顆粒は膜に囲まれることなく，系粒体の基質の内に埋あ れて存在する。この顆粒はさらに微細な粒子の集合体であるという報告 (Luciano ら 1963）ああるが，一般にほぼ均質であるとされている。顆粒は円形ないし卵

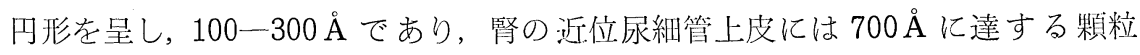
ああるという (Luciano ら 1963). 系粒体の 1 つの断面にみられる顆粒の数は細 胞の種類と状態により異なり，腎の江位尿細管上皮細胞 (Rhodin 1954), 肝細胞 などには特に多いといわれる。Weiss（1955）は水掞よび腸イオンを多く通過させ る細胞には糸粒体内の顆粒が多いと述べた。 また同種の細胞であ機能状態により 系粒体内の顆粒の増減するととを Ito (1962) や Napolitano (1962) が報告してい る。著者の観察では空腹時ラットの十二指腸の吸収上皮細胞では，乙の顆粒は肺 細胞之胃腺副細胞に括けるよりやや少なく，胃腺の主細胞と壁細胞におけるより 多い，しかし，同一ラットの十二指腸吸収上皮細胞であ細胞により差異があり， 一般に絨毛の尖端部の細胞には基底部の細胞よりもその顆粒の数が少なかった。 このととは幼若な細胞には系粒体内顆粒が多いという Schjeide ら（1963）の報告 と一致する。

系粒体内顆粒の化学的組成は現在のところ不明であるが, Schjeide ら (1963) は オスミウムに濃染し, 過酸化水素で漂白されることと, ホルマリン固定標本で屯 電子密度が低いながら観察されることから，との顆粒はリピッドを主成分とし， 少量の金属成分を含有していると考えた。 また Lucianoら（1963）は顆粒を構成 するさらに微細な粒子は鉄を含有するのではないかと述べている.

この系粒体の基質中に存在し, 電子密度が比較的高く, 大きさが径 $100-300 \AA$ でほほぼ円形から卵円形を呈する顆粒を記載の都合上，下文で糸粒体基質内顆粒 と呼ぶことにする。

さて, 今回の実験では, 塩化ナトリウムを給与したラットの十二指腸吸収上皮 細胞に扣いて，糸粒体基質内顆粒の数が増加するのが認められた，基質内顆粒の 数と大きさの変化について, Weiss (1955) はマウスに大量のナトリウムおよびカ リウムを経口的に与えると，基質内顆粒の数が増加するととを報告した，彼は系 粒体基質内顆粒は糸粒体内に分離 (segregate) した陽イオンの形態学的表現であ ると考え, 顆粒の増加は細胞内を過㮃の陽イオンが通過するととを意味すると推 定した. Ito (1962) はコウモリの胃腺壁細胞の糸粒体基質内顆粒が食物の摂取と ともに速やかに消失するととを観察し，Napolitano (1962) は脂肪細胞がリピッド を放出する際に系粒体基質内顆粒が増加し, 細胞内に再びリピッドが増加しはじ めると，顆粒の数と大きさが減少することを観察した。 また Schjeide ら (1963) 
は細胞の幼弱な時期には一般に基質内顆粒の増加がみられ，X 線照射, 饑餓，于 ロキシン投与などにより顆粒が減少するととを実験的に観察している。ささに Peachey (1962，1964) は細胞をカルシウム，ストロンチウムおよびバリウムなど で処理すると，系粒体基質内顆粒が増加することを観察し，乙の増加した顆粒が これら 2 価イオンの沈着物であろうと考えた。 そのほか，上記のような基質内顆 粒とは大きさ形態と組成が異なるが，糸粒体の基質中に現われる特殊な顆粒とし て Bessis ら (1959) のフェリチン顆粒, Policard ら（1961）の珪酸顆粒の報告があ る.

以上の如く，糸粒体基質内顆粒について種々の実験的観察が行なわれている が, この顆粒の生理学的, あるいは病態生理学的な意義については現在のところ 定説がない. しかし，上述の Weiss こPeacheyの説，执よび最近の多くの生化学 的研究, な拈組織化学的研究で証明されている如く (Slater ら 1953, Vasington ら 1962，Raynolds 1960)，糸粒体は種々の陽イオンを蓄積したり運搬したりする働 きをもつと考えられる。著者は系粒体基質内顆粒を系粒体内に蓄積され，あるい は糸粒体内にあって運搬される途中の陽イオンの形態学的現われであろうと考え る者である。

細胞は種々の機能と状態によりイオンの出納を行なう。例えば，主として塩酸 を分泌すると考えられている胃腺の壁細胞では, 分泌にさいして大量の $\mathrm{H}^{+}$と $\mathrm{Cl}^{-}$が失なわれ，乙の時に糸粒体基質内の顆粒も減少または消失するのである. この現象は生体内で広く観察される「需要と供給の法則」にあてはまるあのであ り，塩化ナトリウム給与により十二指腸吸収上皮細胞の糸粒体基質内顆粒が増加 するのあとの法則にあてはまるであろう。

次に，塩化第 1 鉄，硫酸第 1 鉄の給与によって十二指腸吸収上皮細胞，とくに 糸粒体に種々の形態学的な変化がみられたが，よく注目すべきととは糸粒体櫛と 限界膜の内に顆粒が出現したことである。このような糸粒体櫛内の顆粒は最初に Nilsson（1958）によりマウスの増殖期子宮粘膜の立方上皮細胞に観察された。乙

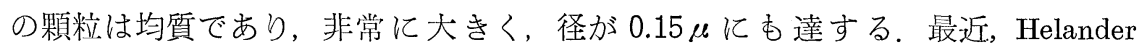
(1959，1962）とDeschner（1963）はそれぞれマウス正常胃腺の副細胞之直腸粘膜 上皮細胞の糸粒体櫛の内に同様の顆粒が存在するのを観察している. 実験的には, Setäläら（1960）はマウスの皮膚に発癌剤である 7,12-dimethylbenzanthracene お よび 3-methylcholanthrene を塗布し，表皮細胞の糸粒体櫛中に電子密度の高い大 きな顆粒の出現するのを見，乙れを発癌作用に特有の変化であると考えた。続い てBurt ら (1961) はマウスに 20-methylcholanthrene を飲ませて前癌状態にある 十二指腸緁毛上皮細胞の糸粒体櫛中に同様の大きな顆粒 $(0.2 \mu)$ が出現するのを 見た。またFrei ら（1961）はマウスの皮膚にクロトン油を塗布し，表皮の胚芽層 の細胞の糸粒体櫛中に同様の顆粒が出現するのを見出し，乙れをいわゆるケラト ヒアリン顆粒の前駆物質であるとした。ささらに，Nakai ら（1962）はマウスの皮 
膚に 7,12-dimethylbenzanthracene やクロトン油を塗布した際にみられる表皮の基 底細胞之立方細胞の糸粒体櫛内の同様の大きさの顆粒は発癌剂の刺激により特異 的に出現したものではなく, 細胞毒に対する反応として現われたあのであると述 べた。

これらの正常粘膜と実験的に刺激した上皮性細胞にみられる糸粒体櫛内の顆粒。 は大きさ, 形態扣よび電子密度が類似するととから同一物であると考えられる. この顆粒の化学的組成ならびに生物学的意義は不明であるが, 前癌状態にのみ現 われる特異的な反応とみるよりは，むしろ種々の刺激に対する非特異的な反応で あると考える方が妥当で, 正常無処置の動物にあ来るのは，それが種々の内的刺 激を常に受けているからであろう。

しかし，塩化第 1 鉄や硫酸第 1 鉄給与により，十二指腸吸収上皮細胞に出現す る糸粒体の限界膜内执よび櫛内の顆粒は大きさ, 構造, 電子密度が明らかに上記 の糸粒体櫛内の大きな顆粒とは異なる。記述の都合上, 著者の観察した糸粒体櫛 内之糸粒体限界膜内の顆粒を糸粒体膜内顆粒と呼んで, Nilsson らのいう櫛内の大 きな顆粒と区別したいのである。

さて, 糸粒体膜内顆粒の出現はいかなる生物学的意義を有するあのであろうか. 大量の 2 価鉄を胃内に注入して十二指腸吸収上皮細胞の糸粒体膜に顆粒が出現し たのである。 大量の鉄は恐らく細胞毒となりうるであろうから，Nakai らのいう 如く刺激による非特異的反応として現われた顆粒。であると考えられないとともな いが，前記の櫛内の大きな顆粒とは明らかに異なった形態学的特徴をそなえてい る。広く生物界の現象を眺めると, 形態が異なれば機能も異なるのが通例である. 著者は，糸粒体膜内顆粒は糸粒体櫛内の大きな顆粒之形態が異なるがために生物 学的意義も異なるものと考える。糸粒体膜内顆粒は鉄液投与後 30 分加ら出現し, 2 時間でピークに達し，6時間後には完全に消失するのであり，Nakai らの刺激に よる顆粒は刺激後 24 時間で出現し，1-2 週間で消失する点からあ，それが全く 異なるあのであるととは明らかである。

本研究では最も吸収されやすい形の鉄である $\mathrm{Fe}^{++}$(Moore. 1944, Hahn 1943, Dubach 1948) をラットに給与して，猃吸収の最も盛んな十二指腸 (Heilmeyer 1958，Brown ら 1958）の吸収上皮細胞の糸粒体膜内に電子密度の非常に高い顆粒 が出現するのが見られたのである。著者はまだての顆粒の化学的性状を究明し得 ないが, この顆粒の出現は恐らく日常の生理的の鉄の吸収と密接な関係があり, さらにとの顆粒は何らかの形の敛の形態学的表現であるものと考えられる。高倍 率で観察すると，顆粒はさらに径が約 $30 \AA$ の微細な粒子からなっていた。この

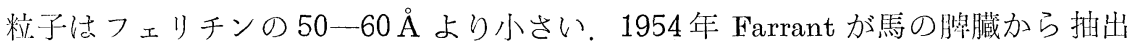
したフェリチンを電子顕微鏡を用いて観察して以来, Richter (1957) や Bessis ら

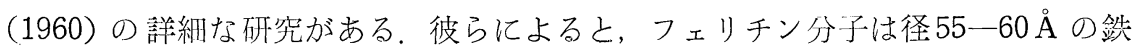
の芯とその周囲を被う径 100一110 の蛋白部分（アポフェリチン）からなり。さ 
らに鉄の芯は正四面体の頂点に位置する径 27-30 の の 6 個の鉄ミセルの集合か らなり，鉄ミセルは水酸化第 2 鉄の形の鉄であるという。著者の観察した微細な 粒子あ径約 $30 \AA$ であり，水酸化第 2 鉄からなる鉄ミセルである可能性が強い.

糸粒体内の鉄代謝について, Bessis (1959) はモルモットの骨䯣赤芽球の糸粒体 の内（櫛の間）にフェリチン，あるいは鉄ミセルを見出し，正常の鉄代謝は糸粒 体の中で行なわれるのではないかと述へ，またRichter（1959）は鉄が 2 価の形で 細胞内に到達した場合，その酸化にあずかるのは糸粒体であろうと考えた，最近 の生化学的知見によれば，糸粒体の膜は種々の酸化還元酵素を含むといわれる。 2 価の鉄イオンが水酸化第 2 猃の形になるには，まず $\mathrm{Fe}^{++}$が糸粒体膜で酸化され $\mathrm{Fe}^{+++}$となり，さらに水酸基を得て（還元） $\mathrm{Fe}(\mathrm{OH})_{3}$ となるあのであろう，した がって, 著者の観察した糸粒体膜内顆粒は糸粒体の膜によって形成された水酸化 第 2 鉄の形態学的表現であろう.

次に，系粒体の基質中にも基質内顆粒とは異なる微細な粒子のまばらな集合が みられたが，乙れあ恐らく膜内顆粒と同様の機桠で作られ，膜をもたないためま ばらな集合を形成したあのと思われる。

膜内顆粒をもった糸粒休には正常ラットおよび塩化ナトリウム給与時にみられ る基質内顆粒は来なかった，著者はとくに系粒体基質内顆粒己膜内顆粒を 1 枚の 写真で対比する目的で両顆粒を併有した糸粒体をさがし求めたが，得られなかっ た．塩化第 1 鉄液を調製するにあたって苛性ソーダのために相当量のナトリウム が混入しているはずである。塩化ナトリウム給与後に糸粒体基質内顆粒が増加す るけれどあ，ナトリウムを含有する塩化第 1 鉄を与えた場合にそれがみられない のは，同時に吸収細胞に達した 2 価イオンと1価イオンが互いに糸粒体に座席争 いするためかも知れない.

また，正常ラットの十二指腸吸収上皮細胞の糸粒体にも種々の変異が認められ， 形態学的には Rouiller ら (1956) のミクロ体, Novikoff ら (1656) のリソソーム, 田中(1962)のセグレソームと区別しがたい糸粒体も存在した（チトリソームと考 えられる)。乙のような糸粒体は限界膜が不明瞭となり, 基質の電子密度が高くな り，糸粒体櫛も時には痕跡をとどめるのみとなる。塩化第 1 鉄給与後 3 時間のラ ットの 1 匹ではこのように変形した糸粒体にも膜内顆粒が存在した。乙れは鉄を 給与したために糸粒体が変形したのではなく，変形した糸粒体もなお膜内顆粒を 非成する能力をあっていると考えるべきであろう。なぜならば，糸粒体はわずか 3 時間でこのような変形を来たさないであろうし，また鉄を給与した他のラット に変形した糸粒体が増加している事実が認められなかったためである。

糸粒体に類似した構造物については古来多くの研究があり, 上記のミクロ体 (microbody), リソソーム (1ysosome), セグレソーム (segresome) のほか, デンス 体 (dense body), オスミウム好性包含体 (osmiophilic inclusion), チトソーム (cytosome）など，実に多くの名称で呼ばれ，その由来む糸粒体からとする Rouiller 
（1956）らの説と, 細胞内の異物処理に当たり糸粒体とは関係のない細胞内小器官 であるとする Novikoff 一派の考えが対立している．著者の今回の観察は，一見 ミクロ体, リソソーム，デンス体などと考えられる構造物のうちに糸粒体の機能 を有するものも存在するととを示し，乙れら構造物の由来を論ずるにさいして興 味のある問題を提唱したものである.

さて，鉄はいかなる経路を通って糸粒体に達するあのであろうか．塩化第 1 鉄 の $3 \mathrm{mg}$ 給与後 30 分間の十二指腸吸収上皮細胞の微絨毛に無数の微細な粒子の付 着している像が観察された。吸収可能な形の鉄を与えて，鉄吸収の最屯盛んであ ると考えられる十二指腸吸収上皮細胞の吸収装置である微絨毛にみられた変化で あるから，乙の像を鉄の吸収像と考えてもよいであろう。この微細な粒子は微絨 毛の基部から尖端部にかけて濔漫性に分布しているが，微䋘毛の基底部の細胞膜 の陣入部には付着していない，乙のことは鉄はいわゆる胞飲 (ピノチトーシス) によって吸収されるのではなく，微絨毛を被う細胞膜を通して拡散されるあので あろう。事実，この微細な粒子は単位膜からなる細胞膜の内面までは追跡される. しかし微絨毛の内部，すなわち細胞質に入ると忽然と姿を消してしまう。その後 この粒子がいかなる形で，どのような経路を通って糸粒体に達するあのであろう か、著者はこの疑問を説明しうる動的な電顕像を得ることができなかったし，ま た従来の諸家の鉄吸収の研究もこれを説明しえない，したがって，ての間の鉄の 運搬経路については推測の域を出ないが，鉄が見えないてとは事実であり，見え ない形の鉄，すなわちイオンの形で通過する可能性が強い．鉄原子は現在のと乙 ろいかなる高性能の電子顕微鏡を用いても観察するととが出来ない. 恐らくは吸 収されたそのままの形の鉄, すなわち $\mathrm{Fe}^{++}$が細胞質を通って糸粒体に達するあ のであろう。この $\mathrm{Fe}^{++}$が糸粒体の膜で酸化され $\mathrm{Fe}^{+++}$となり, さらに水酸基を 得て鉄ミセルを形成するものであると想像されるのである.

次に，糸粒体の膜内に出現した顆粒の運命について考察する。糸粒体膜内顆粒 は塩化第 1 鉄給与の 2 時間後を最高とし以後漸減して, 5 時間以降全く消失した. 著者は乙の顆粒は時間の経過とともに何らかの形態学的な変化を来たすであろう と期待して咩細に観察したが, 数の減少以外には少しの変化あみられなかった. 5 時間以降に見られた糸粒体はすべて正常ラットのものと変わるところがなく， ただ 6 時間後に検べた 2 匹のラットの中 1 匹の十二指晹吸収細胞の細胞質中にフ エリチンと考えられる粒子が集合している像がみられた。この像は糸粒体内で形 成された水酸化第 2 鉄が何らかの代謝をうけてフェリチンとなったてとを示すむ のと思われる. Richter (1959) あ指摘しているように，アポフェリチンは恐らく 小胞体で形成されるものであろう。著者の得た細胞質内のフェリチン集合体の多 くは小胞体によってとりまかれていた。系粒体膜内の顆粒からフェリチンに至る 経路, およびフェリチンのその後の運命については全く追跡し得なかった。また， 6 時間後に検べられた残り 1 匹のラットおよび 5 時間之 8 時間後に検べられたそ 
れぞれ 2 匹にはフェリチンを証明し得なかった。このことは恐らく鉄が吸収細胞 内を通過するに際して, 従来考えられていた如く（Hahn ら 1943, Granick 1951), フェリチンが重要な役割を演ずるあのではないととを示すあのであろう.

最後に, 塩化カルシウムを給与したラットの十二指腸吸収上皮細胞において む, 糸粒体膜内顆粒の出現を観察することができた。 カルシウムも 2 価のイオン として吸収され，糸粒体に達するまでは $\mathrm{Fe}^{++}$と同様の経路をたどり，糸粒体の 膜内で何らかの化合物を作って蓄積するように考えられる. Peachey (1964) は膀 胱上皮および腎臓から分離された細胞をカルシウム，ストロンチウム，バリウム などの 2 価イオンで処理すると，糸粒体の基質中に顆粒が増加するととを認めた。 同じカルシウムでも糸粒体基質中に顆粒を作る場合と糸粒体膜内に顆粒を作る場 合とがあるわけである。乙の差異は恐らく細胞の機能の差異によるものであろ う.

\section{IV. 結 語.}

塩化第 1 鉄, 硫酸第 1 鉄, 塩化カルシウムおよび塩化ナトリウムを経口的に与 えた後のラットの十二指腸吸収上皮細胞の微細構造の変化が観察された.

塩化第 1 鉄給与の30分後に吸収上皮細胞の微絨毛に鉄原子の集合と考えられる 無数の微細な粒子が付着していた。 そして, とくに 1 時間以後に吸収細胞の糸粒 体に著明な变化がみられた。すなわち，その限界膜と櫛の中に $300-500 \AA ̊$ の電 子密度の高い顆粒が多数出現するのであり，乙の顆粒はさらに微細な粒子の集合 からなる。顆粒の数は 2 時間に最も多くなり, 3 時間以後漸減し, 5 時間後には ほとんど認められなくなった。 6 時間後には細胞質の中にフェリチン様粒子の集 合が多数認められる場合もあった。

硫酸第 1 鉄給与の 2 時間後の吸収細胞にも，糸粒体に同様の变化があり，とく に糸粒体の限界膜抢よび楖の内に顆粒が出現した。

塩化カルシゥム給与後のラットにおいても類似した糸粒体の変化がみられた.

塩化ナトリウム給与後に糸粒体の限界膜と櫛の内には顆粒の出現はみられず, ただ，正常ラットにあみられる糸粒体基質内顆粒の数が増加しているのみであっ た。

以上の所見から塩化第 1 鉄之硫酸第 1 鉄などの 2 価の鉄は十二指腸吸収上皮細 胞に颃いては微絨毛にイオン $\mathrm{Fe}^{++}$として吸収され，その後電子顕微鏡で形の捉 えられない $\mathrm{Fe}^{++}$のままで細胞内を行き, それから系粒体に達して酸化され $\mathrm{Fe}^{+++}$ となり，さらに水酸基を得て (還元)，水酸化第 2 鉄からなる鉄ミセルの形とな り，乙れが集合して糸粒体の膜内に顆粒を形成するものであろう。さらに，この 鉄ミセルはアポフェリチンを得てフェリチンとなり，細胞質内を運ばれるものと 考えられる.

また，塩化カルシウム給与時における系粒体の変化と比較検討して，鉄はこれ 
まで考えられていたような特殊な代謝を受けるのではなく，少なくとも糸粒体ま では他の陽イオンと同様の代謝経路をとるあのと考えられる。

\section{Author's Abstruct.}

Fine structural changes of rat duodenal absoptive cells after oral administration of ferrous chloride and sulfate were investigated and compared with those after calcium chloride administration.

Male albino rats of WISTAR strain were fed with iron deficient diet and received nothing but distilled water for 24 hours before experiment. The animals were sacrificed at definite times after intragastric infusion of the above-mentioned chemicals. A portion of the duodenum $2 \mathrm{~cm}$ distal from the pyloric ring was cut, and fixed in buffered osmium tetroxide solution, then dehydrated with alcohol or acetone, embedded in Epon and sectioned with a PORTER-BLUM microtome. Most thin sections were stained with uranium and lead acetate or lead nitrate, and examined by an HU-11A electron microscope.

Mitochondria of the duodenal absorptive cells in normal control rats show no major differences in structure from those of other cells, and particulate matters, 200 to $300 \AA$ in diameter, are seen embedded in the matrix of the mitochondria as previously reported by many authors.

The most remarkable change in many cells induced by $3 \mathrm{mg}$ of ferrous chloride is the appearence of numerous electron dense granules in the cristae and the limiting membrane of mitochondria. These granules are composed of numerous subunits which differ morphologically from ferritin. They increase in number the most after two hours, whereas after thifty minutes and three hours the number of granules is scanty. At thirty minutes many small particles were observed attached to both in and out side of the microvilli of some absorptive cells.

Mitochondrial changes induced by $0.3 \mathrm{mg}$. of ferrous chloride after 3 and 4 hours are for the most part similar to those by $3 \mathrm{mg}$ of ferrous chloride. At 6 hours some aggregations of ferritin-like particles in the cytoplasm are observed surrounded by endoplasmic reticulum or within the so-called cytcplasmic inclusion bodies.

By the administration of $3 \mathrm{mg}$ of ferrous sulfate analogous dense granules are seen in the cristae mitochondriales.

Similar dense granules are also demonstrated in the cristae mitochondriales of rats given calcium chloride, but such granules are never seen in those given sodium chloride.

The dense granules observed in the cristae mitochondriales after administration of ferrous chloride, sulfate or calcium chloride are quite different in size, density, number and structure from other particulate matters in mitochondria reported by many authors. The dense granules in the present study are considered to have a close relationship to the iron absorption.

From the above-mentioned results the author has attained the following conclusion. Iron is absorbed by microvilli of the duodenal absorptive cells and transported to mitochondria in the state of ferrous ion which can not be shown by electron microscope. Then, by oxidation and reduction within the mitochondrial membrane, this ferrous ion becomes to iron micelle which is demonstrable electron microscopically, 
and by the combination with apoferritin in the cytoplasm, the iron micelle might make ferritin. This is the author's conception about iron absorption mechanism.

\section{文献.}

Bessis, M. C. et J. Breton-Gorius : C. r. Acad. Sci. 250 (1960). P. I360. - Blood 14 (1959). P. 423. - Brown, E. B. jr. and B. Justus : Amer. J. Physiol. 194 (1958). P. 315. - Burt, R. C., L. A. Killmeyer, L. R. Thompson and R. C. Granger : Cancer Res. 21 (1961). P. 1427. - Clark, S.L. : J. biophys. biochem. Cytol. 5 (1959). P. 41 . - Caulfield, J. B.: J. biophys. biochem. Cytol. 3 (1957). P. 827. — Dalton, A. J.: Amer. J. Anat. 89 (1951). P. 109. - Dalton, A. J., H. Kahler, M. J. Striebich and B. Lloyd : J. Nat. Cancer Inst. 11 (1950). P. 439. - Deschner, E. E. : Exper. Cell Res. 31 (1963). P. 428. - Essner, E. and A. B. Novikof f : J. ultrastr. Res. 3 (1960). P. 374. - Farrant, J. L. : Biochim. biophys. Acta. 13 (1954). P. 569. - Fawcett, D. W. : In Frontiers in Cytology. New Haven, 1958. P. 19. - Frei, J. V. and H. Sheldon: J. biophys. biochem. Cytol. 11 (1961). P. 724. -Granick, S. : Physiol. Rev. 31 (1951). P. 480. - Granger, B. and R. F. Baker : Anat. Rec. 107 (1950). P. 423. - Hahn, P. F. and W. F. Bale: J. exp. Med. 78 (1943). P. 169. Heilmeyer, L. : Ferritin. In iron in clinical medicine. Berkeley and Los AngeIs, 1958. P. 24. - Helander, H. : J. Ultrastruct. Res. Suppl. 4. 1962. - Helander, H. and R. Ekholm : J. ultrastr. Res. 3 (1959). - - 本陣良平, 津田宏信, 松田 基, 高橋 暁：解剖誌, 36 (1961). 頁 289. — Ito, S. : (Abstr.) 2nd Annual Meeting Amer. Soc. for Cell Biol. 1962. P. 78. — Lacy, D. and A. B. Taylor : J. Anat. 110 (1962). P. 155. - Luciano, L., O. Bucher u. E. Reale: Z. Anat. 123 (1963). S. 543. - Millonig, G.: J. biophys. biochem. Cytol. 11 (1961). P. 736. - Millonig, G. : 5th Internal Congress for Electron Microscopy. New york and London, 1962. P-8. - Nakai, T., P. Schubik and R. Feldman: Exper. Cell Res. 27 (1962). P. 608. Napolitano, L.: J. biophys. biochem. Cytol. 8 (1962). P. 129. - Nilsson, O.: J. Ultastruct. Res. 1 (1958). P. 375. - Novikoff, A. B. : Biol. Bull. 117 (1959). P. 385. - In Developing cell system and their control. New york, 1960. P. 167. - Novikoff, A. B., H. Beaufay and C. De Duve : J. biophys. biochem. Cytol. 2. Suppl. (1956). - Palade, G. E. : Anat. Rec. 114 (1952). P. 427. - Palay, S. L. and L. J. Karlin : J. biophys. biochem. Cytol. 5 (1959). P. 363. - J. biophys. biochem. Cytol. 5 (1959). P. 373. - Peachey, L. D. : 5 th International Congress for Electron Microscopy. New york and London, 1962. P. 00-3. - J. Cell Biol. 20 (1964). P. 95. - Policard, A, A. Collet, H. Daniell-Moussard and S. Pregermain J. biophys. biochem. Cytol. 9 (1961) P. 236. - Raynold, E. S. : J. Cell Biol. 17 (1963). P. 208. - J. Histochem. Cytochem. 8 (1960). P. 331. - Rhodin, J.: In Correlation of ultrastructural organization and function in normal and experimentally changed proximal convoluted tubule cells of the mouse kidney, Stockholm. 1954. - Richter, G. W. : J. exper. Med. 106 (1957). P. 203. - J. exper. Med. 109 (1959). P. 197. - Robertson, J. D. : Biochem. Soc. Symp. 16 (1959). P. 3. - Progr. Biophys. Chem. 10 (1960). P. 343. - Rouiller, C. and W. Bernhard : J. biophys. Biochem. Cytol. 2. Suppl. (1956). - Ruska, C. : Z. Zellforsch. 52 (1960). S. 748. - Setälä, K., L. Merenmies, E. E. Niskanen, M. Nyholm and L. Stjernvall : J. nat. Cancer Inst. 25 (1960). P. 1155. - Schjeide, O. A., R. Mc Candless, M. Wilkens, M. Peterson and G. V. Alexander : Exper. Cell Res. 32 (1963). P. 379. - Sjöstrand, F. S. and J. Rhodin : Exper. Cell Res. 4 (1953). P. 426 . - Schmidt, W.: Z. Zellforsch. 54 (1961). S. 803. - Slater, E. C. and K. W. Cleland : Biochem. J. 55 (1953). P. 566. 一田中春高：最新医学 17 (1962). 頁 206. 一 Vasington, F. D. and J. V. Murphy : J. biol. Chem. 237 (1962). P. 2670. - Weiss, J. : J. exper. Med. 102 (1955). P. 775. - J. exper. Med. 102 (1955). P. 783. - Zetterqvist, H. : In The ultrastructural organization of the columnar absorbing cells of the mouse jejunum, Stockholm, 1956. 